\title{
Abnormal Audit Fees and Audit Quality: \\ Initial Evidence from the German Audit Market
}

\author{
Patrick Krauß \\ Research Associate \\ Research Associate Chair of Accounting and Auditing \\ HHL - Leipzig Graduate School of Management, Jahnallee 59, 04109 Leipzig, Germany \\ E-Mail: patrick.krauss@hhl.de \\ Paul Pronobis \\ Assistant Professor of Accounting \\ Department of Finance, Accounting \& Taxation (FACTS) \\ Freie Universität Berlin, Boltzmannstr. 20, 14195 Berlin, Germany \\ E-Mail: paul.pronobis@fu-berlin.de \\ Henning Zülch \\ Full Professor of Accounting \\ Department Chair of Accounting and Auditing \\ HHL - Leipzig Graduate School of Management, Jahnallee 59, 04109 Leipzig, Germany \\ E-Mail: henning.zuelch@hhl.de
}

Journal of Business Economics (JBE), Forthcoming 


\title{
Abnormal Audit Fees and Audit Quality: \\ Initial Evidence from the German Audit Market
}

\begin{abstract}
This study investigates the economic auditor-client dependency issue by examining the association between abnormal audit fee pricing and audit quality. Our study is the first to analyze this phenomenon empirically for the institutional setting of German IFRS firms by using a sample of 2,334 firm-year observations for the period from 2005 to 2010. Our empirical results demonstrate that positive abnormal audit fees are negatively associated with audit quality and imply that the audit fee premium is a significant indicator of compromised auditor independence due to economic auditor-client bonding. Audit fee discounts generally do not lead to a reduced audit effort, or respectively, audit quality is not impaired when client bargaining power is strong. The association of positive abnormal audit fees and audit quality is robust to different audit quality surrogates such as absolute discretionary accruals, financial restatements, and meeting or beating analysts' earnings forecasts.
\end{abstract}

Keywords: Abnormal Audit Fees, Auditor Independence, Auditor-Client Economic Bonding, Audit Quality, Earnings Management.

JEL-Classification: C30, M41, M42 


\section{Introduction}

On October 13, 2010, the EU-Commission published the green paper "Audit policy: Lessons from the crises" (EU-Commission 2010). The purpose of this regulatory proposal is to provide improvements with regard to statutory audits in the European Union. As one of its key elements for strengthening auditor independence, the green paper proposes a regulatory change to the European audit market where the assignment, remuneration, and duration of the audit engagement should be determined by a third party (for example via a governmental regulator or institution; EU-Commission 2010, p. 11; Quick 2012). Although this proposed regulatory change was not considered in the final proposal for the European Parliament and the European Council (EU-Commission 2011), the EU-Commission has set the issue of auditor appointment and remuneration of audit services on its future agenda.

Almost concurrently with these developments, the accounting profession started to investigate the consequences of abnormal audit fee pricing on auditor independence, and hence audit quality. In general and according to prior literature, auditors who receive abnormally high audit fees are assumed to have an incentive to allow clients to engage in opportunistic earnings management. Economic theory suggests that this relationship holds to the extent that the perceived net benefits of the audit engagement are greater than the associated costs (e.g., Kinney and Libby 2002). In contrast and assuming that audit fees are a measure of audit effort $^{1}$, below-normal audit fees or audit fee discounts might reflect a low level of audit effort (Blankley et al. 2012), or respectively, a strong client bargaining power ${ }^{2}$. Both of these explanations are referred to as audit quality reducing mechanisms. ${ }^{3}$

This study contributes to the audit fee literature in several ways. First, prior empirical studies in the field of abnormal audit fee pricing provide mixed results (e.g., Mitra et al. 2009; Choi et al. 2010; Asthana and Boone 2012; Blankley et al. 2012). Given these mixed results, our study provides additional empirical evidence on the fee-quality association. Second, previous studies in this research area mainly focus on the United States (US) audit market. The main focus on the US audit market leaves uncertainties regarding the direction and magnitude of the empirical relationship in the German environmental context. These uncertainties arise from the different institutional characteristics of Germany in comparison to the US; such as (1) the relatively less restrictive auditor's liability regime, (2) the prevailing two-tier (vs. onetier) corporate governance system, (3) the relatively lower disclosure requirements, (4) the relatively lower liability standards for issuers (including its directors and accountants) and distributors of securities and (5) the relatively lower public enforcement, as well as (6) the different prevailing accounting regimes (i.e., IFRS vs. US-GAAP). These different peculiarities have already been highlighted to result in contradicting audit research results (Schneider et al. 2006; Pott el al. 2009; Quick and Warming-Rasmussen 2009). Consequently, previous US-based audit research studies cannot generally be taken at face value. Rather, separate studies based on German firm data need to be conducted in order to confirm, or respectively, oppose the potential empirical associations of abnormal audit fees and audit quality. Thus, using

1 Please note that we are not able to measure audit effort directly. However, it is reasonable to assume that audit fees are positively correlated with, for example, the working hours of the auditor or the assignment of more experienced staff, both signaling greater effort (Asthana and Boone 2012; Blankley et al. 2012; Eshleman and Guo forthcoming).

2 Also, we are not able to measure client bargaining power directly. However, we do think that audit fee discounts are correlated with the clients' ability to exercise bargaining power (Asthana and Boone 2012; Eshleman and Guo forthcoming).

3 Throughout this paper positive abnormal audit fees and audit fee premiums as well as negative abnormal audit fees, below-normal audit fees, and audit fee discounts, respectively, are used synonymously. 
a sample of 2,334 hand-collected firm-year observations for the sample period 2005-2010, our study is the first attempt to analyze the adverse audit quality consequences of economic bonding due to abnormal audit fees for the German audit market, thereby also adding initial evidence on this subject to the European audit literature. Third, over and above the great amount of empirical evidence with regard to the consequences of non-audit services on audit quality (e.g., Ferguson et al. 2004; Larcker and Richardson 2004; Reynolds et al. 2004; Srinidhi and Gul 2007; Quick and Sattler 2011), an empirical investigation of the association between abnormal audit fees and audit quality is highly relevant, as excessive audit fees might also erode audit quality to a great extent (e.g., Choi et al. 2010). This fact might have been especially amplified by the changes in audit regulation in Germany in 2005 by the Accounting Law Reform Act that restricted many non-audit services in order to strengthen auditor independence. As a consequence of this development, the opportunities of clients to economically bond auditors to accept aggressive and questionable accounting practices have been reduced, or they might have been reallocated from non-audit services to audit services. Though we do not examine a possible reallocation of instruments of economic bonding, investigating the actual situation of auditor-client dependency through abnormal audit fee payments is certainly of similar importance to further shed light on this audit issue.

We choose Germany as our sample country for the following reasons. First, Germany is a country that has an adequate sample size of IFRS accounting data (Ernstberger 2008). Second, German publicly traded companies are required to disclose all fees paid to the assigned statutory auditor since the fiscal year 2005. ${ }^{4}$ Third, from an economical point of view the German audit market is considered as (one of) the most important audit markets in Europe (Quick and Warming-Rasmussen 2009). Thus, the German institutional environment provides the greatest number of firm-year observations with audit fee disclosures for Continental Europe amounting to approx. $20 \%$ of the total European audit market (Heß and Stefani 2012). Accordingly, the study results might be relevant for law-makers and commentators in Europe (Quick and Warming-Rasmussen 2009).

To examine the association of abnormal audit fee pricing and audit quality, we proceed as follows: First and in accordance with prior literature, we estimate a model to come up with abnormal audit fees. Second, we calculate two widely common earnings management proxies by using the discretionary accruals model of Ball and Shivakumar (2006) and the performance-adjusted modified Jones discretionary accruals model (Dechow et al. 1995). Third, the association between positive (negative) abnormal audit fees and discretionary accruals is analyzed empirically in order to test the economic auditor-client dependency issue (reduced audit effort or client bargaining power explanation, respectively). Fourth, we investigate the robustness of our findings by studying the sensitivity of our results to different (positive) abnormal audit fee thresholds. Finally, we examine alternative audit quality surrogates such as financial restatements, first-time going-concern modified opinions, and (just) meeting or beating analysts' earnings forecasts by two cents or less.

Our results show that positive abnormal audit fees are significantly negatively associated with audit quality as measured by our discretionary accruals proxies. In contrast, negative abnormal audit fees generally have an insignificant effect on audit quality. These results imply that the audit fee premium is a significant factor in the context of compromised auditor independence due to economic auditor-client bonding. Conversely, below-normal audit fees do not result in reduced audit effort, or respectively, audit quality does not deteriorate when a strong client bargaining power is immanent. Our findings are robust to different threshold levels of positive abnormal audit fees. However, we find preliminary evidence for the fact that

4 In 2009 the audit fee disclosure requirements are adjusted through the Accounting Law Modernization Act. After the amendment audit fees have also to be disclosed by major non-listed companies that meet certain accounting benchmarks as determined in section 267 paragraph 3 of the German Commercial Code. 
the German accounting enforcement reform (i.e., introduction of the German Financial Reporting Enforcement Panel and the Auditor Oversight Commission, respectively) might have abandoned the adverse consequences of excessive audit fee payments. That is, while our results are robust for the transition period (2005-2007) of the German accounting enforcement reform, abnormal audit fees do not affect audit quality for the period of higher regulatory strength (2008-2010). Nevertheless, in order to investigate the robustness of the consequences of the German enforcement reform on audit quality, future research is necessary. In our final tests for robustness using alternative audit quality surrogates, we are generally able to confirm that positive abnormal audit fees are negatively associated with audit quality. Here, we also find evidence that negative abnormal audit fees increase the probability of a financial restatement as well as the likelihood of just meeting or beating the median analysts' earnings forecast. In contrast, the probability to issue a first-time modified going-concern opinion is not affected when above-normal, or respectively, below-normal audit fees are paid.

In summary, discriminating between positive and negative abnormal audit fees is important when analyzing the auditor-client dependency issue. Further, alternative audit quality measures might result in conflicting results. However, the results could also be biased by endogeneity in general and omitted variables in particular as audit fees, non-audit fess and abnormal accruals could be jointly determined (Antle et al. 2006). For example, abnormal accruals from complex accounting transactions (such as inventory run-ups, mergers and acquisition, etc.) could cause the company to demand additional audit and/or non-audit services to mitigate audit risk. Alternatively and to the extent that our audit fee model does not fully capture risk characteristics, a risky company might demand higher audit fees but at the same time only allow low audit quality. ${ }^{5}$ As a consequence of the caveats inherent in audit quality studies such as ours, the research results at hand should be interpreted cautiously. ${ }^{6}$

The paper at hand is structured as follows: Section 2 presents the theoretical background and the hypotheses development. Section 3 sets up the research design while section 4 discusses the sample composition and presents the respective descriptive statistics. In section 5 we show the empirical results of our study. Section 6 presents additional sensitivity tests as well as robustness checks using alternative audit quality surrogates. The final section 7 contains our conclusions and some reflections on the limitations with regard to our research design.

\section{Background and Hypotheses Development}

According to prior literature, audit firms that receive abnormally high audit fees have the incentive to allow clients to engage in opportunistic earnings management (e.g., Kinney and Libby 2002; Choi et al. 2010). The reason for this is usually referred to as the economic theory of auditor independence (DeAngelo 1981a; DeAngelo 1981b) where the desire to maintain a profitable audit engagement with (abnormally) high audit fee payments is traded off against the cost associated with a potential litigation and/or reputational damage (Johnson et al. 2002). ${ }^{7}$ To the extent that the perceived net benefits are greater than the associated costs,

\footnotetext{
We thank the anonymous reviewer for this insight.

6 As Eshleman and Guo (forthcoming) point out, research should work on developing refined measures of audit quality.

7 The Arthur Anderson - Enron case can be seen as a prime example for the trade-off between economic benefits and the desire to uphold a firm's reputation. Arthur Andersen, a large international audit company with a 90-years firm history and total revenues of nine billion dollars had to shut down its business within three months after the state attorneys detected irregular auditing practices within the Enron audit engagement (Alexander et al. 2002). Kinney and Libby (2002) note in this context that Enron's actual audit fees paid in the fiscal year 2000 were 250 percent of the estimated normal audit fees.
} 
the economic bonding effect increases and audit quality simultaneously decreases. Consistent with this assumption, Dye (1991) and DeFond et al. (2002) argue that audit quality could be impaired when fee rents are paid. Accordingly, while discussing the study of Frankel et al. (2002), Kinney and Libby (2002) also note that a strong economic bonding between the auditor and its client will reduce the quality of reported earnings through the auditor's curbed willingness to resist client-induced biases in the accounting figures reported. ${ }^{8}$

Besides the existence of audit fee premiums, it is also possible that clients pay less than the expected level of audit fees, namely audit fee discounts. When auditors receive abnormally negative audit fees, they have fewer incentives to compromise audit quality, as the net benefits from the audit engagement do not outweigh the potential cost for an incorrect audit report (e.g., reputation loss, claims for compensation). However, prior studies like Gupta et al. (2009) and Blankley et al. (2012) argue that audit quality can be impaired by audit fee discounts as audit firms adjust their audit effort, and respectively, their audit procedures downwards; i.e., decreasing audit hours, assigning less experienced staff, etc. (Gregory and Collier 1996; Eshleman and Guo forthcoming). As an alternative explanation, below-normal audit fees might reflect a stronger client bargaining power which, in turn, has been shown to be associated with a lower audit quality (Barnes 2004).

Prior empirical findings with regard to abnormal audit fee pricing and audit quality are inconsistent. The study of Higgs and Skantz (2006) find a positive relationship between earnings response coefficients, a measure of perceived audit quality, and abnormal audit fees. In contrast the study of Hoitash et al. (2007) provides evidence that audit quality is negatively associated with abnormal total fees. However, the authors are unable to find statistically robust results for abnormal audit and non-audit fees. Accordingly, Hribar et al. (2010) shows that unexpected audit fees are negatively associated with audit quality. Further, Gupta et al. (2009) find that negative abnormal audit fees are negatively associated with audit quality while positive abnormal audit fees are an insignificant factor in this context. Contrary to these findings, Xie et al. (2010) find that abnormal audit fees are generally not associated with audit quality whereas Mitra et al. (2009) show that normal and abnormal audit fees are both positively associated with audit quality. The study results of Choi et al. (2010) provide evidence that audit quality decreases as the magnitude of abnormal positive audit fees increases. But then, the authors are not able to find a statistically significant association between negative abnormal audit fees and the quality of the conducted audit. In contrast to Choi et al. (2010), the study of Blankley et al. (2012) again illustrates that positive abnormal audit fees have a positive effect on audit quality, while the study of Asthana and Boone (2012) provides evidence that positive and negative abnormal audit fees are both significantly negatively associated with audit quality. Finally, Eshleman and Guo (forthcoming) find a positive relationship between abnormal audit fees and audit quality. Possible reasons for the mixed findings are difficult to resolve as different samples, sample periods, audit quality measures, estimation models and control variables are used. ${ }^{9}$ However, the shift from the pre-Sarbanes-Oxley Act (SOX) to the post-SOX regulatory regime seems to generally have strengthened auditor independence (Asthana and Boone 2012) while also influencing the magnitude of the relationship between financial reporting risk and audit fees. In this context, Charles et al. (2010) show that the magnitude of the risk-audit fee relationship has doubled between the pre-SOX and postSOX regulatory regimes.

8 For example, Bedingfield and Loeb (1974) find that disputes over accounting principles are a significant factor for clients to change their auditor.

9 For example, Eshleman and Guo (forthcoming) argue that the mixed findings in this research field are primarily caused by the choice of the audit quality proxy. 
Table 1 presents additional details on the sample period, the sample size, the main audit quality measure as well as the country of investigation of previous literature on the audit quality effects of abnormal audit fee pricing. As can be seen there, the majority of prior research studies proxies audit quality via discretionary accruals. Alternatively, financial restatements, audit opinions, analysts' earnings forecasts, earnings response coefficients, fraud incidences, or SEC comment letters, respectively, are used as surrogates for audit quality. It can also be noted, that 9 out of the 10 studies identified examine the US audit market. The remaining study by Xie et al. (2010) provides initial empirical evidence for the Chinese audit market. Hence, there is yet no empirical evidence for the European or German audit market, respectively.

\section{[Table 1]}

To add initial evidence in order to close this research gap, our study analyzes the adverse audit quality consequences of economic bonding - due to abnormal audit fees - for the German audit market. We find this research focus worthwhile and contributing to current literature for several important reasons relating to the different institutional characteristics of Germany in comparison to the US (where - as discussed above - most of previous research has focused on). The individual issues listed below add up to the conclusion that - from an ex ante point of view - it remains unclear whether abnormal audit fee pricing within the German environmental context is related to discretion within the financial statements, and hence a lower audit quality. Also, and as stated in prior literature, the different German audit market peculiarities are expected to lead to different audit research results in comparison to prior studies from the US (Pott et al. 2009; Quick and Warming-Rasmussen 2009).

First, an auditor's liability regime could have a significant impact on the auditor's net economic bonding incentives ${ }^{10}$ which, in turn, (negatively) affect audit quality. The civil liability for auditor's misbehavior is sanctioned differently in Germany and the US. In the German environmental context, the liability of compensatory damages is limited to $€ 4$ million, ${ }^{11}$ while there is unlimited liability for audit firms in the US (Quick and Warming-Rasmussen 2009). Moreover, in the US there exist third party liabilities as well as class actions. However, in Germany, no third party liabilities arise as a consequence of misbehavior during the audit work and class actions are only possible in very few cases (Bigus and Zimmermann 2008). ${ }^{12}$ In this context, La Porta et al.'s (2006) liability standard index also implies that the burden of proof in auditor litigation cases is much higher in Germany than in the US (Ratzinger-Sakel 2013). Overall, the auditor's liability regime in Germany is considered to be less restrictive than the one in the US (Gietzmann and Quick 1998; Bigus and Zimmermann 2008; Quick and Warming-Rasmussen 2009; Ratzinger-Sakel 2013). As a consequence, the lower litigation risk of the auditor within the German environmental context is expected to negatively affect

10 We define the auditor's net economic bonding incentives to be the potential rents of compromising audit independence (and keeping the mandate) less the potential associated costs of low quality reporting (e.g., litigations, reputation loss, etc.). See DeAngelo (1981a; 1981b) for a discussion of the auditor's trade-off between audit rents and independence.

11 The liability of compensatory damages is limited by the German Commercial Code, section 323, paragraph 2 to a maximum amount of $€ 1$ million for audits of non-listed companies and to a maximum amount of $€ 4$ million for audits of listed companies.

12 Please note that traditional and recent legal practice by the Federal Court of Justice in Germany ("Bundesgerichtshof") points out that section 323 (paragraph 1, sentence 3) of the German Commercial cannot be used as the basis for claims by third parties. However, an exception exists if the audit contract between the statutory auditor and the client explicitly includes a third party liability clause. In addition, it is worth noting that there also exist alternative opinions on the notion whether auditor misbehavior can give rise to third party liabilities in Germany. Please refer to Seibt and Wollschläger (2011) for further details. 
audit quality when the magnitude of positive abnormal audit fees increases. Negative abnormal audit fees might also deteriorate audit quality in the German environmental context as a reduced audit effort is likely to result in lower (potential) litigation charges.

Second, the limited liability corporations in Germany follow a two-tier corporate governance structure while in the Anglo-Saxon countries like the US; a one-tier corporate governance system prevails. In this context the US one-tier setting is primarily characterized by the board of directors (Köhler et al. 2008). In contrast the German two-tier corporate structure consists of the executive board (German Stock Corporation Act, section 76) and the supervisory board. The executive board is responsible for strategic and operational decision making, while the supervisory board appoints (German Stock Corporation Act, section 84) and monitors (German Stock Corporation Act, section 111) the executive board. Furthermore, the supervisory board represents employees' interests through the concept of co-determination (Tuschke and Sanders 2003) and maintains networks with stakeholders. ${ }^{13}$ The monitoring task of the supervisory board also comprises the examination of the financial statement reporting process. Among other things, this examination is supported by the findings and remarks of the statutory auditor. ${ }^{14}$ Thus, the statutory auditor can be seen as a close partner or agent of the supervisory board (Köhler et al. 2008; Quick and Warming-Rasmussen 2009). Due to the clear segregation of duties with regard to executive power and oversight, we assume that the net economic bonding incentives for auditors in a two-tier setting are smaller than in a onetier setting where the segregation of duties is not that strong. For example, in the US one-tier setting CEO and board chairman position can either be held by two different persons, or respectively, by the same person (Krause and Semadeni 2013). Consequently, we expect the German two-tier governance system to positively affect audit quality when positive abnormal audit fees are paid. In case of below-normal audit fees, audit quality might also differ systematically in the two jurisdictions when the supervisory board or respectively, audit committee renegotiates the financial terms of the audit differently; inducing a lower audit quality level when the auditor reduces her effort in order to make the audit engagement profitable (Telberg 2010; Blankley et al. 2012).

Third, the institutional environment in Germany is significantly different from the one existing in the US. For example, La Porta et al. (2006) assesses the institutional setting in Germany to be less restrictive with regard to disclosure requirements, liability standards for issuers (including its directors and accountants) and distributors of securities, and public enforcement. ${ }^{15}$ In addition, Djankov et al. (2008) finds that legal protection of minority shareholders against expropriation by corporate insiders is lower in Germany relatively to the US. Furthermore and referring to Glaum et al. (2004), the corporate governance and ownership system in Germany is classified as an "insider system", which is characterized by a low information asymmetry between the management and the owner of the cooperation (La Porta et al. 1997; Leuz et al. 2003). In this context the study of Leuz et al. (2003) has shown that "out-

13 The composition of a supervisory board of a limited liability company in Germany is characterized by explicitly involving various stakeholders; e.g., banks, blockholders, employees and/or trade union representatives (Hackethal et al. 2005, p. 398-401). In addition, see Lane (2003) and Goergen et al. (2008) for a discussion on the differences and the convergence of the German and Anglo-American corporate governance model.

14 It is important to note that the supervisory board of a public limited company is obliged by the German Stock Corporation Act (section 124 paragraph 3, sentence 1) to propose a statutory auditor to the shareholders' meeting. After the formal voting of the members of the shareholders' meeting the supervisory board is also entitled to assign the auditor for the upcoming annual financial statement audit (German Commercial Code, section 318, paragraph 1, sentence 1; German Stock Corporation Act, section 119, paragraph 1, No. 4 ).

15 Please note that the public enforcement index equals the average of the following sub-indices: (1) supervisor characteristics index; (2) rule-making power index; (3) investigative powers index; (4) orders index; and (5) criminal index. 
sider" economies with relatively dispersed shareholders, strong outside investor protection, and large equity markets like the US exhibit lower levels of earnings management than "insider" countries such as Germany with relatively concentrated shareholders, weak investor protection, and less developed equity markets (Leuz et al. 2003). According to the aforementioned study results, we expect the less restrictive institutional environment in Germany - in comparison to the US - to increase auditor's net economic bonding incentives, and thus, negatively affect audit quality when positive abnormal audit fees are paid. ${ }^{16}$ Furthermore, negative abnormal audit fees are likely to result in a relatively lower audit quality when being reflective of a reduced audit effort or a stronger client bargaining power, respectively.

Finally, the US accounting regime is based upon the Anglo-American accounting system (US-GAAP), while the German accounting system is partially based upon IFRS. ${ }^{17}$ Prior research suggests that the aforementioned accounting systems generally lead to divergent and non-comparable accounting figures (Barth et al. 2012). Accordingly, empirical studies which are based on archival data from the two prevailing accounting systems might show different results.

In summary and due to the reasons mentioned above, the previous studies conducted for the US jurisdiction are not transferable to the unique German institutional setting. Rather, separate studies based on German firm data need to be conducted in order to confirm or oppose the potential empirical associations of abnormal audit fees and audit quality. Similarly, prior contradicting research results in the field of non-audit services and auditor independence have been attributed to different legal environments (Schneider et al. 2006; Pott el al. 2009). Please note, however, that the concurrent study does not try to disentangle the different peculiarities of the German setting, but instead, tries to gain an overall understanding of the specific auditor-client dependency issue due to abnormal audit fee pricing in the German environmental context.

Consistent with the aforementioned arguments and given prior empirical findings, we do not know ex ante and for the German institutional setting whether positive abnormal audit fees have a negative impact on auditor independence, and hence audit quality. Moreover, we are unable to provide a satisfying prediction about the potential audit quality effects of negative abnormal audit fees in the German environmental context from an ex ante point of view. Consequently, we test the following two non-directional hypotheses:

Hypothesis (1): Positive abnormal audit fees are not associated with audit quality.

Hypothesis (2): Negative abnormal audit fees are not associated with audit quality.

16 The German law-maker enacted the Accounting Enforcement Act as of December 15, 2004. The act created the basis for the implementation of a two-tier financial reporting enforcement in Germany. In addition the German law-maker enacted the Auditor Oversight Law as of December 27, 2004. The act introduced the Auditor Oversight Commission (APAK) in Germany, which is among other things responsible for disciplinary oversight of German auditors. We are not sure if and how those accounting reforms are considered in the study results by La Porta et al. (2006). However, it can be assumed that those reforms have improved the public enforcement characteristics in the German institutional setting. Please refer to Ernstberger et al. (2012) for further details of the accounting enforcement reforms in Germany. Please also note our additional robustness analysis in section 6, on the effects of the regulative changes in the German audit environment.

17 The German law-maker enacted the Accounting Law Reform Act as of December 4, 2004. The act became effective for fiscal years beginning on or after January 1, 2005. The act contained the rules for the mandatory IAS/IFRS adoption for listed companies in Germany and substantially modified the existing regulations on auditor independence. 


\section{Research Design}

\subsection{The Model of Abnormal Audit Fees}

Choi et al. (2010, pp. 115-116) define abnormal audit fees as the difference between the client's actual audit fees paid to the auditor (for the annual financial statement audit) and the expected normal level of fees that should have been charged for the audit engagement effort. Based on this definition, audit fees could be separated into two components: (1) normal audit fees, and (2) abnormal audit fees. According to the algebraic sign, the latter component could further be separated into audit fee discounts or audit fee premiums. Normal audit fees are considered to capture the effects of the regular audit effort costs (i.e., personal expenses for the audit team, litigation risks, and normal profit margin for the audit engagement (Simunic 1980; Choi et al. 2008; Choi et al. 2009; Mitra et al. 2009), whereas abnormal audit fees are determined through a non-transparent, and therefore, unobservable auditor-client agreement (Choi et al. 2010).

Following Simunic (1980), the recent audit fee literature (Craswell et al. 1995; DeFond et al. 2002; Hay et al. 2006; Choi et al. 2010) provides evidence that the demand for audit services is a positive function of the following three audit engagement factors: (1) client size, (2) client complexity, and (3) audit engagement specific risk (i.e., both the risk of the client and the auditor). Based on the empirical results of the aforementioned studies, we calculate the audit fee model as presented in Equation (1), in which the estimated coefficients are used to compute the normal or expected audit fees for each firm-year. ${ }^{18}$ Then, the abnormal audit fees are calculated as the difference between the actual audit fees paid and the normal audit fees estimated (Francis and Wang 2005; Mitra et al. 2009). The variables used in Equation (1) are defined in Appendix 1.

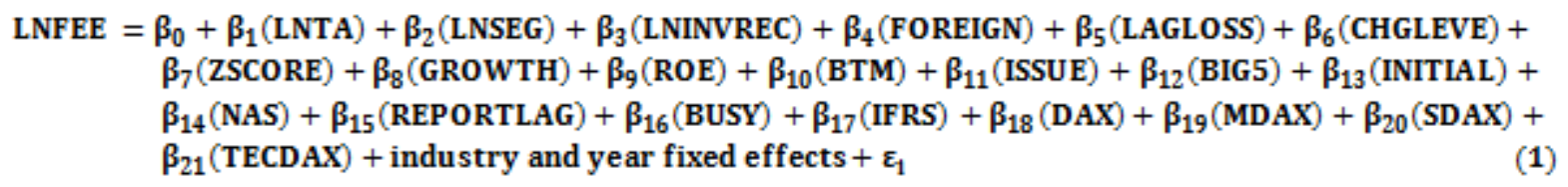

We include LNTA to proxy for client size. The results of prior empirical audit fee studies (e.g., Simunic 1980; Hay et al. 2006; Hoitash et al. 2007; Choi et al. 2010; Eshleman and Guo forthcoming) provide evidence that the level of audit fees is positively associated with the size of the audited company. In addition, prior research also suggests that the demand for audit services is positively associated with the complexity of the client's business and audit environment. To proxy for client complexity, we add the variables LNSEG, LNINVREC and FOREIGN (Simunic 1980; Hay et al. 2006; Choi et al. 2008; Choi et al. 2010) to Equation (1).

We include the variables LAGLOSS, CHGLEVE, ZSCORE, GROWTH, ROE ${ }^{19}$, BTM and ISSUE to control for client-specific risks. For example, when firms face financial problems the litigation risk of the auditor is higher than for profitable and/or financially healthy clients. To be compensated for the higher risk associated with financially distressed mandates, in turn, the auditor is assumed to charge higher fees (Simunic 1980; Pratt and Stice

18 Throughout this paper, we omit subscripts for the firm and year for the sake of brevity when presenting our model equations.

19 With regard to the study of Hay et al. (2006) the majority of prior empirical audit fee studies used other profitability measures (e.g., ROA, etc.). Due to several collinearity issues with other independent control variables we decide to use ROE as a proxy for profitability. 
1994; Simunic and Stein 1996; Hay et al. 2006; Eshleman and Guo forthcoming). Furthermore, we assume that the level of audit fees differs systematically between high growth firms and low growth firms (Reynolds et al. 2004; Hay et al. 2006; Choi and Wong 2007; Choi et al. 2010). On the one hand, high growth firms can be seen as less risky clients for auditors as the growth rates indicate a healthy business environment. On the other hand, particularly fast growing firms have to face significant changes in their business organization and the related accounting systems, which can often lead to a greater demand for audit services. To capture these growth effects, we add the variables GROWTH, BTM and ISSUE to our regression model.

Besides client's risk characteristics, the audit fee estimation model is also designed to capture auditor's risk characteristics. To control for audit firm size and reputation effects, we utilize the binary variable BIG5. Audit fee premiums should be expected when an auditor has gained a certain reputational status and is considered to deliver superior audit quality (DeAngelo 1981b; Palmrose 1986a; Craswell et al. 1995; Ireland and Lennox 2002) ${ }^{20}$ Further, the variable INITIAL is added to the model to control for fee-cutting effects at first-year audit engagement bids (DeAngelo 1981a; Eshleman and Guo forthcoming). Regardless of the specific audit pricing practices in the first year of the audit engagement, prior research suggests that a change of the audit firm should always be considered in an audit fee estimation model (Simon and Francis 1988; Turpen 1990; Deis and Giroux 1996). NAS is another explanatory variable, which has been commonly used in previous audit research (Simunic 1984; Palmrose 1986b; Whisenant et al. 2003). On the one hand, it is argued that the provision of non-audit services can lead to lower audit fees because of synergy and knowledge spillover effects which both could lead to an increased efficiency in the audit process (Hay et al. 2006; Joe and Vandervelde 2007; Quick and Warming-Rasmussen 2009). On the other hand, non-audit services could be associated with higher audit fees, because such services may lead to extensive changes in a firm's organization which require additional audit effort (Simunic 1984; Turpen 1990; Hay et al. 2006). Referring to the study of Hay et al. (2006), we additionally include the variables REPORTLAG and BUSY. REPORTLAG is used as an indicator for the efficiency of the statutory audit conducted (Hay et al. 2006; Choi et al. 2010), while BUSY controls for specific audit pricing practices during the busy season (Hay et al. 2006; Mitra et al. 2009). Both variables are expected to be positively associated with LNFEE. In addition, we include the binary variable IFRS in order to capture potential first-time IFRS adoption effects on the level of audit fees in the German audit market (Bigus and Zimmermann 2009).

With respect to client complexity, we also add the indicator variables DAX, MDAX, SDAX and TECDAX to Equation (1). These individual indicator variables take the value of 1 if the sample firm is respectively listed in one of the four indices of the Frankfurt Stock Exchange. Due to the structure of the capital market and the related public disclosure requirements, it can be assumed that the audit of these companies is more complex, and thus, more costly than for (smaller) non-index firms (Köhler et al. 2010). Finally, the audit fee estimation model contains 10 industry indicator variables as defined by Frankel et al. (2002) and modified by Ernstberger et al. (2013). ${ }^{21}$ The model is estimated using industry-fixed effects as well as year-fixed-effects in order to control for potential industry- and year-heterogeneity.

20 Given the German audit market peculiarities, we define the following audit firms to be Big 5 auditors: KPMG, Ernst \& Young, Deloitte, PWC, and BDO.

21 According to Ernstberger et al.'s (2013) German setting modification of Frankel et al.'s (2002) industry membership, the classification is defined by SIC code as follows: agriculture (0100-0999), mining and construction (1000-1999, excluding 1300-1399), consumer manufactures (2000-2111, 2200-2799), chemicals, pharma, and refining (1300-1399, 2800-2824, 2830-2836, 2840-2899, 2900-2999), durable manufactures (3000-3999, excluding 3570-3579 and 3670-3679), transportation (4000-4899), utilities (49004999), retail (5000-5999), services (7000-8999, excluding 7370-7379), and computers (3570-3579, 3670$3679,7370-7379)$. 


\subsection{Models of Earnings Management}

Audit quality is not directly observable (Asthana and Boone 2012). Therefore and in accordance with prior research, we primarily focus on common proxies for earnings management as our audit quality measures (Lim and Tan 2008; Davis et al. 2009; Choi et al. 2010; Asthana and Boone 2012).

For our study we estimate two popular discretionary accrual models in order to determine audit quality: (1) the model of Ball and Shivakumar (2006), and (2) the modified Jones model (Dechow et al. 1995). Both models are widely used in auditing and accounting research studies (e.g., Choi et al. 2010). As suggested by McNichols (2000) and Kothari (2001), we also control for firm performance in the modified Jones model by using the ROA variable, as non-discretionary accruals are highly correlated with past and current firm performance. ${ }^{22}$ Moreover, we estimate both of the models for the full sample of German listed firms by year and for each industry (Choi et al. 2010; Asthana and Boone 2012; Ernstberger et al. 2013) using a total of 2,838 firm-year observations (results are available upon request). Thereby, we require a minimum of ten observations for all year-industry combinations.

The Ball and Shivakumar (2006) model as well as the performance-adjusted modified Jones model (Dechow et al. 1995) are illustrated in Equation (2) and, respectively, Equation (3) below.

$$
\begin{aligned}
\mathrm{TACC}_{\mathrm{it}} / \mathrm{TA}_{\mathrm{it}-1}= & \beta_{0}+\beta_{1}\left(1 / \mathrm{TA}_{\mathrm{it}-1}\right)+\beta_{2}\left(\left[\Delta \mathrm{REV}_{\mathrm{it}}-\Delta \mathrm{REC}_{\mathrm{it}}\right] / \mathrm{TA}_{\mathrm{it}-1}\right)+\beta_{3}\left(\mathrm{PPE}_{\mathrm{it}} / \mathrm{TA}_{\mathrm{it}-1}\right)+ \\
& \beta_{4}\left(\mathrm{CFO} / \mathrm{TA}_{\mathrm{it}-1}\right)+\beta_{5}\left(\mathrm{DCFO}_{\mathrm{it}}\right)+\beta_{6}\left(\left[\mathrm{CFO}_{\mathrm{it}} / \mathrm{TA}_{\mathrm{it}-1}\right] * \mathrm{DCFO}_{\mathrm{it}}\right)+\varepsilon_{\mathrm{i}}
\end{aligned}
$$

$$
\begin{aligned}
\mathrm{TACC}_{\text {it }} / \mathrm{TA}_{\text {it }-1}= & \beta_{0}+\beta_{1}\left(1 / \mathrm{TA}_{\mathrm{it}-1}\right)+\beta_{2}\left(\left[\Delta \mathrm{REV}_{\mathrm{it}}-\Delta \mathrm{REC}_{\mathrm{it}}\right] / \mathrm{TA}_{\mathrm{it}-1}\right)+\beta_{3}\left(\mathrm{PPE}_{\mathrm{it}} / \mathrm{TA}_{\mathrm{it}-1}\right)+ \\
& \beta_{4}\left(\mathrm{ROA} / \mathrm{TA}_{\mathrm{it}-1}\right)+\varepsilon_{\mathrm{i}}
\end{aligned}
$$

where for client firm $i$ in year $t$, the variables are defined in Appendix 1. Our discretionary accrual measures (i.e., $|\mathrm{DA} 1|$ and $|\mathrm{DA} 2|)$ are derived from the absolute value of the residuals $\left(\varepsilon_{\mathrm{i}}\right)$.

\subsection{Measuring the Association between Abnormal Audit Fees and Earnings Management}

To test our two hypotheses described in section 3, we posit the following regression model in Equation (4) linking the magnitude of unsigned discretionary accruals (i.e., |DA1| and |DA2|) with our variable of interest: namely abnormal audit fees (ABAFEE). To differentiate the effects of positive abnormal audit fees from negative abnormal audit fees, we use the dummy variable DPABAFEE and the multiplicative interaction term PABAFEE (DPABAFEE*ABAFEE). The variables used in Equation (4) are defined in Appendix 1.

$$
\begin{aligned}
\mid \text { DA1 } \mid \text { or } \mid \text { DA2 } \mid= & \beta_{0}+\beta_{1}(\text { ABAFEE })+\beta_{2}(\text { DPABAFEE })+\beta_{3}(\text { PABAFEE })+\beta_{4}(\text { LNTA })+\beta_{5}(\text { AGE })+ \\
& \beta_{6}(\text { BTM })+\beta_{7}(\text { GROWTH })+\beta_{8}(\text { ISSUE })+\beta_{9}(\text { CFO })+\beta_{10}(\text { LOSS })+ \\
& \beta_{11}(\text { CHGLEVE })+\beta_{12}(\text { ZSCORE })+\beta_{13}(\text { BIG5 })+\beta_{14}(\text { INITIAL })+\beta_{15}(\text { LAGTACC })+ \\
& \text { industry and year fixed effects }+\varepsilon_{1}
\end{aligned}
$$

Consistent with prior empirical audit fee studies (e.g., Choi et al. 2010; Asthana and Boone 2012), a number of independent control variables are added to the model. LNTA is included to capture any firm size effects which might be correlated with our earnings man-

22 Please note that the Ball and Shivakumar (2006) model already controls for firm performance by incorporating the $\mathrm{CFO}$ variable. 
agement measures. Prior studies find that large firms report a relatively lower level of discretionary accruals in comparison to smaller firms (Dechow and Dichev 2002). It is assumed that large listed companies are under increased public, legislative, and accounting research scrutiny which curbs the extensive reporting of discretionary accruals (Johnson et al. 2002; Choi et al. 2010). Moreover, we add AGE to Equation (4) because long-time existing firms are expected to have more sophisticated business processes and financial reporting systems in place (Johnson et al. 2002). Therefore, we expect that AGE is negatively associated with |DA1| and |DA2|, respectively. In addition, we include BTM, GROWTH, ISSUE and CFO to capture the consequences of firm-growth and firm performance on earnings management behavior (Becker et al. 1998; Dechow and Dichev 2002; Frankel et al. 2002; Choi et al. 2010). The variables LOSS, CHGLEVE, and ZSCORE are added to the estimation model in order to control for debt and financial distress (Dechow and Dichev 2002; Choi et al. 2010; Asthana and Boone 2012). In particular firms with high debt ratios are expected to have greater incentives to improve earnings in order to meet specific debt agreements such as debt covenants or to avoid a bankruptcy declaration (DeFond and Jiambalvo 1994; Johnson et al. 2002, Choi et al. 2010). Therefore, we assume that all three variables are positively associated with both of the dependent variables. Moreover, BIG5 is used as a proxy for audit firm size (Asthana and Boone 2012) as previous research in auditing suggests that large audit firms (i.e., Big 4 or Big 5 auditors) are expected to provide higher audit quality than smaller audit firms. Thus, the Big 5 companies are able to detect and limit the reporting of unusually high (discretionary) accruals (Becker et al. 1998; Francis et al. 1999; Choi et al. 2010). Referring to the study of DeFond and Subramanyam (1998), we also include the binary variable INITIAL which takes the value of 1 if there is an auditor change in the current fiscal year, and 0 otherwise. Following Reynolds et al. (2004) and Choi et al. (2010), we add lagged total accruals (LAGTACC) to the estimation model in order to capture the variation of total accruals over time (Becker et al. 1998). Finally and consistent with Equation (1), the model is estimated using industry-fixed and year-fixed-effects to control for potential industry- and year-heterogeneity, respectively.

\section{Sample and Descriptive Statistics}

\subsection{Sample Composition}

Our analyses use data from all German non-financial companies with IFRS consolidated financial statements that were listed in the regulated market of the Frankfurt Stock Exchange between 2005 and $2010{ }^{23}$ The focus on one capital market automatically controls for institutional factors such as regulatory and listing requirements, or the enforcement system. Furthermore, Germany is a country that has an adequate sample size of IFRS accounting data (Ernstberger 2008). To be included in our sample, firms must have financial information available (i.e., total assets and net income) in the Thomson Reuters Worldscope database. In accordance with other empirical research in this area, all companies with the SIC codes 6000 up to 6999 (i.e., banks, insurance companies and financial firms) are excluded as the balance sheet structures of these firms are fundamentally different to those of non-financial firms and would not allow a comparison. Our initial IFRS sample thus contains 607 companies. In order to collect audit fee data for these companies, a total of 2,704 audited annual reports were retrieved using databases for financial statements (e.g., "www.hvinfo.de"), the firms' homepages as well as the electronic German company register ("www.unternehmensregister.de"). Next, we have to adjust our initial sample for the following reasons. First, we exclude 137 firm-year observations due to missing audit fee

23 The IFRS classification follows Daske et al. (2013). As some regression variables are based on information of the previous period, data of the fiscal year 2004 is also included in our analyses. 
disclosures. ${ }^{24}$ Second, we reduce the sample by 86 firm-year observations that disclose the audit fees paid to the international network of the audit firm but do not provide information on the portion of the audit fees paid to the engaged German auditor. ${ }^{25}$ Thus, we consistently use the audit fees paid to the German audit firm that are disclosed as mandated by the German Commercial Code (section 314, paragraph 1, No. 9). Third, we delete 17 firm-year observations with a shortened fiscal year. Fourth, we do not consider 14 firm-year observations due to the fact that these are joint audits. Fifth, we exclude 12 firm-year observations because of reporting irregularities; i.e., substantive future restatements of audit fee disclosures. Finally, we exclude another 104 firm-year observations due to missing control variables for Equation (1) and Equation (4).

As a consequence of these adjustments, the final study sample contains audit fee data of 537 companies or 2,334 firm-year observations. ${ }^{26}$ Table 2, Panel A summarizes the aforementioned sample adjustments and presents the final sample composition derived. Panel $\mathrm{B}$ indicates the yearly distribution of audit fee observations, while Panel C shows the sample of observations according to Frankel et al.'s (2002) industry classification (modified by Ernstberger et al. 2013).

\section{[Table 2]}

\subsection{Descriptive Statistics}

The descriptive statistics of the variables used in Equation (1) and (4) are presented in Table 3. We winsorize all continuous variables at the 1 percent, and respectively, 99 percent level to control for outliers. With regard to the distribution of variables shown in Table 3, it is worth noting the following facts. First, the mean (median) values of both discretionary accrual measures (i.e., |DA1| and |DA2|) amount to 7.8 (4.7) and 10.0 (6.0) percent of lagged total assets, respectively. Second, after delogging the variables LNFEE, LNTA, and LNSEG on the individual firm-year level, it can be shown that the average (median) company in our sample paid audit fees of $443 \mathrm{k} €(165 \mathrm{k} €)$, has total assets of $€ 1,618$ Mio. ( $€ 126$ Mio.) and operates in 3.6 (4.0) business segments. Other noteworthy aspects of our sample composition are an average (median) revenue growth of 12.0 (5.8) percent, an average (median) return on equity of 7.9 (9.0) percent, and an average (median) book-to-market ratio of 71.8 (59.9) percent.

Our sample also shows plausible frequencies for our binary variables. The binary variable for audit fee premiums (DPABAFEE) amounts to 52.1 percent, which shows that our sample has an almost equal distribution of firm observations with positive and negative abnormal fees, respectively. Moreover, it is also worth highlighting that 26.9 percent of our sample firms report a negative net income in the sample period. In addition, 12.0 percent of the audit engagements in our sample are first-year mandates, while 64.4 percent are audited by a Big 5 auditor. These descriptive figures imply that five large (international) audit firms dominate the German audit market and that an auditor change is quite infrequent for listed

24 The missing audit fee disclosures are mainly related to the alternative fiscal year-end (i.e., not December 31 ) of some companies for which the mandatory fee disclosure requirements were not yet binding in 2005 .

25 This issue is mainly driven by the legal restructuring of KPMG in Europe. In October 2007, KPMG Germany, KPMG United Kingdom and KPMG Switzerland merged to form KPMG Europe LLP. During the period under study, the KPMG offices of the Netherlands, Spain, Belgium, Luxembourg, Norway, Russia, Ukraine, Kyrgyzstan, Kazakhstan, Armenia, Georgia, Saudi Arabia, Jordan and Kuwait have joined KPMG LLP.

26 The audit fee data was hand-collected by one of the authors as well as by research assistants. All numbers were validated by another author, not involved in the initial collection process. 
clients. ${ }^{27}$ Next, we note that 87.9 percent of the sample firms have their fiscal year-end during December (BUSY). Finally, 8.2 percent of the firm-year observations are first-time IFRS adopters. $^{28}$

Overall, the descriptive statistics of the remaining control variables are generally comparable with those of other German audit fee studies (Bigus and Zimmermann 2009; Köhler et al. 2010).

\section{[Table 3]}

Table 4 presents both the Pearson and the Spearman correlation matrix of the variables used in Equation (4). The correlation matrix shows that our audit quality measures (i.e., |DA1| and $|\mathrm{DA} 2|)$ are highly correlated with each other $\left(\rho_{\mathrm{s}}=0.4517 ; \rho_{\mathrm{p}}=0.5951\right)$. Further, the matrix also displays that ABAFEE is not significantly correlated with |DA1| or |DA2|, respectively. In addition, the majority of the control variables used in Equation (4) is significantly correlated with both dependent variables, suggesting a multivariate analysis in order to discriminate their effects on the level of discretionary accruals.

With regard to the correlations between the control variables used in Equation (4), it is worth noting the following: First, LNTA is significantly correlated with AGE $\left(\rho_{\mathrm{s}}=0.3144\right.$; $\left.\rho_{\mathrm{p}}=0.3535\right)$ and BIG5 $\left(\rho_{\mathrm{s}}=0.3902 ; \rho_{\mathrm{p}}=0.3851\right)$. These correlations suggest that large firms have a longer company history and are more likely to hire a Big 5 auditor than a small or midsized company. Second, Table 4 shows that LOSS is significantly correlated with ZSCORE $\left(\rho_{\mathrm{s}}=0.4084 ; \rho_{\mathrm{p}}=0.4378\right)$ and CFO $\left(\rho_{\mathrm{s}}=-0.4434 ; \rho_{\mathrm{p}}=-0.3323\right)$. This correlation highlights the obvious fact that firms which report a negative net income are more likely to go bankrupt as well as to suffer from lower (negative) levels of operating cash flows. Finally, ZSCORE and CHGLEVE are also significantly positively correlated with each other $\left(\rho_{\mathrm{s}}=0.2711\right.$; $\left.\rho_{\mathrm{p}}=0.3991\right)$.

To conclude, the Pearson-Spearman correlation matrix implies that the estimated models are unlikely to suffer from multicollinearity problems.

\section{[Table 4]}

\section{Empirical Results}

\subsection{Results for the Model of Abnormal Audit Fees}

Table 5 presents the results obtained by estimating our audit fee model in Equation (1). The model is estimated using a pooled sample ${ }^{29}$ of 2,334 firm-year observations over

27 It is important to note, however, that the audit market concentration is lower in comparison to many other countries (for example, the BIG4 control approx. $80 \%$ of the US audit market). See Asthana and Boone (2012), Table 3.

28 A majority of German listed companies used an option enacted by the Capital Raising Act in 1998 to prepare the annual consolidated statement in accordance with IFRS (or US-GAAP) instead of German GAAP before 2005. As a consequence, Germany is a country where a considerable amount of IFRS annual financial statements is available for a relatively long time period (Ernstberger 2008).

29 We use a cross-sectional estimation approach where we cluster heteroscedasticity-adjusted standard errors on the firm-level. The cross-sectional estimation approach follows prior literature such as Choi et al. (2010), Asthana and Boone (2012), and Blankley et al. (2012). Please note that a firm fixed effect estimation could result in an understatement of the true standard error when the residuals of a given firm are correlated across years for a given firm (Petersen 2009). In addition, a pooled estimation approach generally increases the statistical power in comparison to firm fixed effect computations. 
a six year period (2005-2010), and includes industry- as well as year-fixed-effects. ${ }^{30}$ The fitted values of this regression help us to separate the normal audit fee component from the abnormal audit fee component. ${ }^{31}$

As can be seen in Table 5, 12 out of 21 explanatory variables are significantly associated with the dependent variable LNFEE, thereby explaining a significant portion of the total variation (adjusted $\mathrm{R}^{2}$ of 81.9 percent). ${ }^{32}$ Moreover, the coefficient signs of all statistically significant variables are in line with our expectations, and hence, with prior research (e.g., Hay et al 2006; Choi et al. 2010). Accordingly, it can be concluded that our audit fee model is appropriate to determine abnormal audit fees.

The results in Table 5 provide some additional insights with respect to the German audit market characteristics. First, BIG5 is significantly positively associated with LNFEE. This result indicates that Big 5 audit firms are in the position to claim higher fee rates than non-Big 5 auditors. ${ }^{33}$ In other words, German listed companies are willing to pay for audit quality differentiation between Big 5 and non-Big 5 audit firms. In contrast, the coefficient of INITIAL is significantly negatively associated with the dependent variable. This negative regression coefficient suggests that audit firms in the German audit market systematically offer fee discounts at initial audit engagement bids in order to gain new mandates. The fee-cutting finding is supported by empirical evidence of Köhler et al. (2010). Finally, all four index indicator variables (i.e., DAX, MDAX, SDAX, and TECDAX) are positively associated with LNFEE. As already described above, we assume that the increased disclosure requirements in the premium indices of the Frankfurt Stock Exchange lead to more (complex) audit procedures which, in turn, result in higher audit fee rates (Köhler et al. 2010).

\section{[Table 5]}

\subsection{Testing the Association between Abnormal Audit Fees and Earnings Management}

Table 6 provides the results of testing the association between abnormal audit fees and earnings management where $|\mathrm{DA} 1|$ and $|\mathrm{DA} 2|$, respectively, are used as the dependent variables. As explained above, we add the variables ABAFEE, DPABAFEE as well as the interaction term ABAFEE*DPABAFEE (PABAFEE) in order to distinguish the effect of positive abnormal audit fees from the effect of negative abnormal audit fees. The overall effect of positive abnormal audit fees on earnings management is captured by the sum of the two coefficients of DPABAFEE and PABAFEE, while the single coefficient of ABAFEE represents the effect of negative abnormal audit fees on earnings management.

The results for both of our accrual measures are qualitatively similar. Table 6 shows that ABAFEE is neither significantly correlated with |DA1| nor with |DA2|, respectively, indicating that auditors are able to provide an appropriate level of audit quality even when audit fees are below the normal level. Moreover, these results imply that low audit fee rates are not

30 Excluding the industry- and year-fixed effects does not alter our results qualitatively.

31 Throughout this study the presented t-values are all calculated on an adjusted basis, using robust standard errors corrected for heteroscedasticity and firm-level clustering (Petersen 2009).

32 In comparison, other German audit market studies as for instance Bigus and Zimmermann (2009), Köhler et al. (2010) and Wild (2010) show similar adjusted $\mathrm{R}^{2}$ of approx. 82 percent for their audit fee models.

33 The significant positive coefficient is in line with the study results of Köhler et al. (2010), although the authors used the binary variable BIG4 in their research approach. Moreover, the results are partially supported by the findings of Wild (2010). The author states that among the Big 4 auditors only PWC is able to earn fee premiums in the German audit market. However, the empirical evidence of Wild (2010) cannot be taken at face value as the study mainly focus on audit pricing practices after auditor changes. 
necessarily compensated through a reduction in audit effort. In contrast, the coefficient of PABAFEE is significantly positively associated with both dependent accrual variables. Moreover, the sum of the coefficients of DPABAFEE and PABAFEE is also significantly positively associated with $|\mathrm{DA} 1|$ (sum of the coefficients $=0.01839$; $\mathrm{p}$-value $<0.05$; not tabulated), and respectively, $|\mathrm{DA} 2|$ (sum of the coefficients $=0.03423$; $\mathrm{p}$-value $<0.01$; not tabulated). The results support the rejection of our Hypothesis (1). Excessive audit fees payments are an important incentive for auditors to allow their clients to engage in opportunistic earnings management, thus, decreasing the quality of a firm's financial statements. Conversely, we provide no empirical evidence that audit fee discounts negatively influence audit quality because of a reduced audit effort, or respectively, a strong client bargaining power. Therefore, we are unable to reject Hypothesis (2).

Besides our variables of interest, Table 6 shows that the majority of the explanatory variables are significantly associated with $|D A 1|$ and $|D A 2|$, respectively. Since the results for both estimation models are qualitatively similar, we focus our discussion on the results reported for the $|\mathrm{DA} 2|$-model. As expected and consistent with prior studies (e.g., Johnson et al. 2002), AGE is significantly negatively associated with |DA2|. In addition, our proxies for firm growth and performance (i.e., GROWTH, ISSUE, and CFO) are positively associated with our discretionary accruals measure. Moreover and also consistent with previous literature (e.g., Dechow and Dichev 2002; Choi et al. 2010; Asthana and Boone 2012), our results for |DA2 indicate that financially distressed and loss making firms tend to have higher levels of discretionary accruals. Consequently, the explanatory variables LOSS and ZSCORE are significantly positively associated with the dependent variable. Furthermore, the negative association reported for BIG5 implies that large audit firms in the German audit market provide a qualitatively higher audit than non-Big 5 auditors. Finally, LAGTACC is significantly negatively associated with $|\mathrm{DA} 2|$ confirming the need to control for variations in the reversal of accruals over time (Choi et al. 2010).

Overall, the results in Table 6 provide empirical evidence that excessive audit fee payments can impair auditor independence and lead to a higher magnitude of discretionary accruals, hence a lower audit quality. As a matter of fact, audit fee premiums should be considered as an important factor in the context of economic auditor-client bonding and the related dependency issues. Finally, our empirical evidence for negative abnormal audit fees shows that audit fee discounts are a subordinate factor in an auditor-client relationship (e.g., client bargaining power) or for the assessment of appropriate audit effort levels by the audit firm. As presented above, our results support the empirical evidence of Choi et al. (2010) while being in conflict with the findings of Mitra et al. (2009), Asthana and Boone (2012), Blankley et al. (2012), and Eshleman and Guo (forthcoming).

\section{[Table 6]}

\section{Additional Tests for Robustness}

Since our proxy for abnormal audit fees is still likely to be subject to misspecification, some of the results reported in the aforementioned section could be affected by measurement error. Thus, we perform a variety of robustness checks to strengthen the confidence in our results.

First, we further investigate the relationship of positive abnormal audit fees and audit quality by conducting a sensitivity analysis where we re-estimate Equation (4) for different threshold levels of positive abnormal audit fees (i.e., 1 percent, 2 percent, 5 percent, and respectively, 10 percent of total audit fees). The estimation is intended to account for the fact 
that there could be a normal range instead of a normal level of audit fee pricing. Consequently, we deem to reveal whether an increase in positive abnormal audit fees results in a systematic decrease in the quality of the audit conducted. That is, we hypothesize that audit quality is a decreasing function of the abnormal audit fees paid to the statutory auditor. Table 7 demonstrates the results of these procedures for $|\mathrm{DA} 1|$, while Table 8 presents the results for |DA2|. As can be seen in Table 7, the coefficient for ABAFEE is insignificant for all of our four audit fee thresholds. In accordance with our main analysis above, abnormal audit fees have an insignificant impact on audit quality when ABAFEE is $<0$, or respectively, below the respective thresholds (i.e., within some "normal" range ${ }^{34}$ ). In contrast, the results for all specifications of PABAFEE are significantly positively associated with |DA1|. In Table 8, we find ABAFEE to be insignificant for the 1 percent audit fee threshold. However, for higher abnormal audit fee thresholds (i.e., 2 percent, 5 percent and 10 percent of total audit fees, respectively) ABAFEE shows a significantly negative association with |DA2|. This provides some evidence for a positive effect of audit fee pricing within a certain "normal" range. Again, the results for all PABAFEE threshold specifications are significantly positively associated with our discretionary accruals metric. Overall, we can derive the following conclusions from these sensitivity analyses: We confirm that audit quality is a decreasing function of the abnormal audit fees paid. In other words, audit quality is especially impaired when positive abnormal audit fees are high. For positive abnormal audit fees that exceed $10 \%$ of total audit fees, the magnitude of the association with $|\mathrm{DA} 1|$ is greater than for the lower abnormal audit fee thresholds. With respect to |DA2|, we are even able to observe a monotonic increase for the different PABAFEE thresholds specifications. As both discretionary accruals measures imply similar directions for the association between positive abnormal audit fees and audit quality, we infer that our results are mainly driven by the firm-year observations with higher levels of positive abnormal audit fees while the lower levels of positive abnormal audit fees have only a moderate effect on the quality of the audit conducted.

\section{[Tables 7 \& 8]}

Second, prior research implies that discretionary accruals are a noisy proxy for audit quality (Hoitash et al. 2007, p. 783). That is, the conflicting results of our study and the previous evidence of Asthana and Boone (2012) and Blankley et al. (2012), respectively, could be due to the use of alternative audit quality surrogates. For example, Blankley et al. (2012) used financial restatements as the audit quality surrogate, while Asthana and Boone (2012) proxied audit quality by the probability of (just) meeting or beating analysts' earnings forecasts by two cents or less. ${ }^{35}$ In order to investigate whether our empirical findings are robust to alternative audit quality specifications, we re-estimate Equation (4) using both of the aforementioned alternative audit quality surrogates. Furthermore, we follow Ernstberger et al. (2013) and use the likelihood to issue going-concern-modified audit reports as an additional audit quality proxy, thereby adding initial evidence with respect to the relationship of abnormal audit fees and going-concern opinions. To test the association of abnormal audit fees and the alternative audit quality surrogates, we posit the regression models presented in Equation (5) and Equation (6), respectively. In Equation (5), our abnormal audit fee variables are linked to the probability of a financial restatement (RESTATE) ${ }^{36}$ as well as to the probability of issuing a first-

34 Please note that we do not try to specifically derive a normal range of audit fee pricing nor to disentangle its economic consequences, but leave this promising topic for future research.

35 Asthana and Boone (2012) used discretionary accruals as an audit quality proxy in their main analysis, too.

36 The dependent variable RESTATE refers to the publication of error findings established by the German twotier enforcement system. The German enforcement system consists of a private review panel, namely the 
between ABAFEE and MBEX as the dependent variable for the sub-sample of firms which are followed by financial analysts. The negative coefficient for ABAFEE yields an increase in the predicted odds of MBEX of $119.64 \%$ when the negative abnormal audit fees decrease by 1-unit (i.e., increase in magnitude). Again, the coefficient for PABAFEE, and respectively, for the sum of the coefficients DPABAFEE and PABAFEE (sum of the coefficients = 1.34292 ; $p$-value $<0.05$; not tabulated) are significantly positively associated with the likelihood of (just) meeting or beating analysts' earnings forecasts by two cents or less. A 1-unit increase in the magnitude of positive abnormal audit fees indicates a $283.02 \%$ increase in the respective odds predicted.

However, the probability of receiving a first-time GCO cannot be explained by the level of (positive or negative) abnormal audit fees. This result is consistent with RatzingerSakel (2013) and again highlights the issue of conflicting results due to the use of alternative audit quality measures (Eshleman and Guo forthcoming).

In summary, we find significant adverse effects for both negative, and respectively, positive abnormal audit fees on audit quality for two out of three alternative audit quality surrogates. On the one hand, the results of the aforementioned robustness analyses imply that our empirical findings are robust for the audit quality consequences of abnormal positive audit fees. On the other hand, our initial results for abnormally negative audit fees seem not to be robust with regard to alternative audit quality measures. That is, the alternative audit quality surrogates show that auditors do not provide an appropriate level of audit effort when belownormal audit fees are paid (i.e., client bargaining power is strong). However, we leave the discrimination of the inconsistent results for negative abnormal audit fees (i.e., discretionary accruals vs. alternative audit quality measures) to future research.

\section{[Table 9]}

As a third robustness test, we exploit the fact that the German regulatory system was affected by major changes during the period from 2005 to 2010. The most important changes were the introduction of the German Financial Reporting Enforcement Panel (FREP - DPR) as well as the creation of the Auditor Oversight Commission (AOC - APAK). ${ }^{39}$ In order to investigate whether our results are affected by these German accounting enforcement reforms, we conduct subsample analysis for the transition period from 2005 to 2007, and respectively, the period of relatively strong regulatory oversight from 2008 to 2010 . Our untabulated results demonstrate that positive abnormal audit fees are significantly negatively associated with audit quality for the transition period 2005-2007. However, for the period of higher regulatory strength (2008-2010), our coefficients for positive abnormal audit fees are insignificant. ${ }^{40}$ According to Ernstberger et al. (2013) the changing regulatory environment might have motivated the auditors to expend additional effort during their audits. In our opinion, respectively, the auditors' potential costs of an incorrect audit report (e.g., reputation loss, deprivation of auditors' certification, claims for compensation, etc.) might have increased so that they outweigh the incentives to allow audit clients engaging in opportunistic earnings management. Again, we leave this promising avenue of investigation for future research. ${ }^{41}$

For our final robustness testing, we re-estimate the regression models using non-audit fees and total fees (i.e., the sum of audit fees and non-audit fees), respectively, as previous

39 Please refer to Ernstberger et al. (2012) for further details as well as capital market consequences of the German accounting enforcement reform.

40 The coefficients for negative abnormal audit fees are insignificant for both of the subsample periods.

41 These findings are similar to the enhanced auditor independence in the years following the enactment of SOX. See Asthana and Boone (2012) for further details. 
studies have primarily focused on the relative importance of non-audit fees or total fees instead of single audit fees (e.g., Kinney et al. 2004; Hoitash et al. 2007; Lim and Tan 2008; Paterson and Valencia 2011). Thus, we use the natural log of non-audit fees and, respectively, total fees as the dependent variable in Equation (1). In accordance with our study approach, we compute abnormal non-audit fees and abnormal total fees from Equation (1) and test the association between the respective fee variables and our earnings management measures according to Equation (4). The untabulated results of our robustness-check for abnormal total fees provide qualitatively similar results for positive abnormal total fees and |DA1|, whereas we are not able to find significant results for the association of positive abnormal total fees with |DA2|. The results for the abnormally negative total fee measures are insignificant. Overall, the untabulated insignificant results for abnormal non-audit fees are in line with prior nonaudit service studies (e.g., DeFond et al. 2002; Kinney et al. 2004; Larcker and Richardson 2004). ${ }^{42}$

\section{Conclusions and Limitations}

In this study, we analyze the empirical association between abnormal audit fees and audit quality, as measured by discretionary accruals. Consistent with recent literature on audit fee pricing, we separate abnormal audit fees into positive, and respectively, negative components to better capture the different economic effects of the two fee constructs on audit quality. Using a sample of 2,334 firm-year observations for the period from 2005 to 2010, our empirical results demonstrate that positive abnormal audit fees are negatively associated with audit quality. In contrast, negative abnormal audit fees have an insignificant effect on audit quality. Our results imply that the audit fee premium is a significant factor in the context of compromised auditor independence due to economic auditor-client bonding. Furthermore, we provide evidence that audit fee discounts do not result in a reduction of audit effort, or respectively, audit quality is not reduced when client bargaining power is strong. These findings are robust to different threshold levels of positive abnormal audit fees. While our results also remain robust for the transition period (2005-2007) of the German accounting enforcement reform (i.e., introduction of the German Financial Reporting Enforcement Panel and the Auditor Oversight Commission, respectively), we are unable to find significant results for the period of higher regulatory strength (2008-2010). However, in order to investigate the robustness of the audit quality effect of the enforcement reform, future research is necessary. In that regard it seems important to further shed light on whether and how the changing regulatory environment might have motivated the auditors to expend additional audit effort. Further, it seems worthwhile to investigate whether the auditors' potential costs of an incorrect audit report (reputation loss, loss of auditors' certification, claims for compensation, etc.) might have increased as a consequence of the changing regulatory environment.

In additional robustness tests with alternative audit quality surrogates, we are able to confirm that positive abnormal audit fees are negatively associated with the quality of the audit conducted. This association holds true for financial restatements and meeting or beating analysts' earnings forecasts. In contrast, however, these alternative audit quality surrogates show that auditors are also not in the position to provide an appropriate level of audit effort when below-normal audit fees are paid, or alternatively, audit quality seems to be impaired when client bargaining power is strong. Again, studies are requested to investigate the reasons of the different negative abnormal audit fee effects on the continuous proxy of audit quality

42 Quick and Sattler (2011) conduct an empirical study of the effects of non-audit services on audit quality for the German audit market. Using working capital accruals as a measure of audit quality, the authors find insignificant results for both audit-related and tax fees. However, the study provides evidence that other (consulting) fees are positively associated with the magnitude of working capital accruals. 
(i.e., discretionary accruals) in comparison to the respective binary proxies of audit quality (i.e., financial restatements, and meeting or beating analysts' earnings forecasts). As we are not able to find an association between the probability of receiving a first-time modified GCO and the level of (positive or negative) abnormal audit fees, further investigations are also needed here. Summing up, the issue of conflicting results due to the use of alternative audit quality surrogates is critical and should be addressed by future research (Eshleman and Guo forthcoming).

Our study adds empirical evidence to the inconsistent and comprehensible range of existing abnormal audit fee literature, which is mainly concentrated on the US audit market. Moreover, to the best of our knowledge, this study is the first to analyze the effects of abnormal audit pricing on audit quality for the German audit market. From a regulatory perspective, our study provides useful insights into the recent debates regarding the economic auditorclient dependency issue. In the wake of the concurrent discussions of the EU-Commission regarding the appointment, remuneration and duration of statutory audits, our results partly support the implementation of audit market price controls through a public institution or agency as suggested by the European Commission (EU-Commission, 2010, p. 11). However, this conclusion is drawn cautiously as it remains subject to subsequent empirical tests to confirm the association of abnormal audit fees and audit quality for other European jurisdictions.

Overall, our empirical evidence should not be taken at face value but rather interpreted with caution because the research design is subject to the following limitations. First, our main study approach assumes that discretionary accruals are an appropriate measure of earnings management, and thus, are also inversely related to audit quality. Despite the widely accepted use in prior accounting research, discretionary accruals are often criticized as a noisy proxy for the quality of the audit conducted. Though we consider the effects of performance differences among firms in our estimations, our results might be subject to measurement error rather than a reflection of audit quality. Furthermore, we conduct several sensitivity and robustness tests to strengthen the confidence in our results. Over and above, our sample covers a timeframe affected by significant business and regulatory changes (e.g., mandatory IFRS adoption, initial application of audit fee disclosure requirements, financial and economic crises, etc.) that may lead to a high diversity in audit fee disclosures. We attempt to address these issues by hand-collecting our audit fee data, adding year-fixed effects into our regression models and conducting several robustness-checks. However, we cannot rule out the possibility that the fee classifications are subject to systematically biased judgments that may affect the results of our study. Third, though we compute abnormal audit fees using an audit fee estimation model that appears to be well-specified and in line with the results of prior audit fee studies, we cannot rule out the possibility of an unknown degree of model misstatement; i.e., due to endogeneity and correlated omitted variables. In particular, audit fees, non-audit fees and abnormal accruals could be determined by the same underlying process (Antle et al. 2006), or respectively, our audit fee model might not be able to fully capture risk characteristics which are correlated with both audit fees and abnormal accruals. Finally, our sample composition is based on publicly traded German firms. Therefore, our results may not be generalizable to non-public companies. Future research should consider this limitation and investigate the German, or respectively, European private firms context. 


\section{Literature}

Alexander D, Burns G, Manor R, McRoberts F, Torriero E (2002) The fall of Andersen: Greed tarnished golden reputation. The Chicago Tribune, September 1-4, 2002: 1, (17).

Allison PD (2005) Logistic regression using the SAS system: Theory and application. SAS Institute Inc., Cary, North Carolina.

Antle R, Gordon E, Narayanamoorthy G, Zhou L (2006) The joint determination of audit fees, non-audit fees, and abnormal accruals. Review of Quantitative Finance and Accounting 27(3): 235-266.

Asthana SC, Boone JP (2012) Abnormal audit fee and audit quality. Auditing: A Journal of Practice \& Theory 31(3): 1-22.

Ball R, Shivakumar L (2006) The role of accruals in asymmetrically timely gain and loss recognition. Journal of Accounting Research 44(2): 207-241.

Barnes P (2004) The auditor's going concern decision and Types I and II errors: The Coase theorem, transaction costs, bargaining power and attempts to mislead. Journal of Accounting and Public Policy 23(6): 415-440.

Barth ME, Landsman WR, Lang HL, Williams CD (2012) Are IFRS-based and US GAAPbased accounting amounts comparable? Journal of Accounting \& Economics 54(1): 68-93.

Becker C, DeFond M, Jiambalvo J, Subramanyam K (1998) The effect of audit quality on earnings management. Contemporary Accounting Research 15(1): 1-24.

Bedingfield J, Loeb S (1974) Auditor changes - an examination. Journal of Accountancy 137(3): 66-69.

Bigus J, Zimmermann R-C (2008) Non-audit fees, market leaders and concentration in the German audit market: A descriptive analysis. International Journal of Auditing 12(3): 159-179.

Bigus J, Zimmermann R-C (2009) Quasirentenmodell und Honorare für Abschlussprüfungen in Deutschland - eine empirische Analyse. Journal of Business Economics (ZfB Zeitschrift für Betriebswirtschaft) 79(11): 1283-1308.

Blankley AI, Hurtt DN, MacGregor JE (2012) Abnormal audit fees and restatements. Auditing: A Journal of Practice \& Theory 31(1): 79-96.

Carey PJ, Geiger MA, O'Connell BT (2008) Costs associated with going-concern-modified audit opinions: An analysis of the Australian audit market. ABACUS 44(1): 61-81.

Charles, SL, Glover SM, Sharp NY (2010) The association between financial reporting risk and audit fees before and after the historic events surrounding SOX. Auditing: A Journal of Practice \& Theory 29(1): 15-39.

Choi J-H, Kim J-B, Liu X, Simunic DA (2008) Audit pricing, legal liability regimes, and Big 4 premiums: Theory and cross-country evidence. Contemporary Accounting Research 25(1): 55-99.

Choi J-H, Kim J-B, Liu X, Simunic DA (2009) Cross-listing audit fee premiums: Theory and evidence. The Accounting Review 84(5): 1429-1463.

Choi J-H, Kim J-B, Zang Y (2010) Do abnormally high audit fees impair audit quality? Auditing: A Journal of Practice \& Theory 29(2): 73-97.

Choi J-H, Wong TJ (2007) Auditors' governance functions and legal environments: An international investigation. Contemporary Accounting Research 24(1): 13-46. 
Craswell AT, Francis JR, Taylor SL (1995) Auditor brand name reputations and industry specializations. Journal of Accounting and Economics 20(3): 297-322.

Daske H, Hail L, Leuz C, Verdi R (2013) Adopting a label: Heterogeneity in the economic consequences around IAS/IFRS adoptions. Journal of Accounting Research 51(3): 495-547.

Davis LR, Soo BS, Trompeter GM (2009) Auditor tenure and the ability to meet or beat earnings forecasts. Contemporary Accounting Research 26(2): 517-548.

DeAngelo LE (1981a) Auditor independence, "low balling" and disclosure regulation. Journal of Accounting and Economics 3(2): 113-127.

DeAngelo LE (1981b) Auditor size and audit quality. Journal of Accounting and Economics 3(3): 183-199.

Dechow P, Dichev I (2002) The quality of accruals and earnings. The Accounting Review 77: 35-59.

Dechow P, Sloan R, Sweeney A (1995) Detecting earnings management. The Accounting Review 70(2): 193-225.

DeFond M, Jiambalvo J (1994) Debt covenant effects and the manipulation of accruals. Journal of Accounting and Economics 17(1-2): 145-76.

DeFond M, Raghunandan K, Subramanyam K (2002) Do non-audit services fees impair auditor independence? Evidence from going concern audit opinions. Journal of Accounting Research 40(4): 1247-1274.

DeFond M, Subramanyam K (1998) Auditor change and discretionary accruals. Journal of Accounting and Economics 25(1): 35-67.

Deis D, Giroux G (1996) The effect of auditor changes on audit fees, audit hours, and audit quality. Journal of Accounting and Public Policy 15(1): 55-76.

Djankov S, La Porta R, Lopez-de-Silanes F, Schleifer A (2008) The law and economics of self-dealing. Journal of Financial Economics 88(3): 430-465.

Dye RA (1991) Informationally motivated auditor replacement. Journal of Accounting and Economics 14(4): 347-374.

Ernstberger J (2008) The value relevance of comprehensive income under IFRS and US GAAP: Empirical evidence from Germany. International Journal of Accounting, Auditing and Performance Evaluation 5(1): 1-29.

Ernstberger J, Koch C, Tan H-T (2013) Lead auditor expertise, audit quality, and audit fees. Working Paper.

Ernstberger J, Stich M, Vogler O (2012) Economic consequences of accounting enforcement reforms: The case of Germany. European Accounting Review 21(2): 217-251.

Eshleman JD, Guo P Abnormal audit fees and audit quality: The importance of considering managerial incentives in tests of earnings management. Auditing: A Journal of Practice $\&$ Theory (forthcoming).

European Commission (EU-Commission) (2010) Green paper. Audit policy: Lessons from the crises.

Available at: http://ec.europa.eu/internal_market/auditing/reform/index_en.htm.

European Commission (EU-Commission) (2011) Proposal for a regulation of the European Parliament and the Council on specific requirements regarding statutory audit of publicinterest entities.

Available at: http://ec.europa.eu/internal_market/auditing/reform/index_en.htm. 
Ferguson MJ, Seow GS, Young D (2004) Nonaudit services and earnings management: UK evidence. Contemporary Accounting Research 21(4): 813-841.

Francis JR, Maydew EL, Sparks HC (1999) The role of Big 6 auditors in the credible reporting of accruals. Auditing: A Journal of Practice \& Theory 18(2): 17-34.

Francis JR, Wang D (2005) Impact of the SEC's public fee disclosure requirement on subsequent period fees and implications for market efficiency. Auditing: A Journal of Practice \& Theory 24(Supplement): 145-60.

Frankel R, Johnson M, Nelson K (2002) The relation between auditors' fees for non-audit services and earnings quality. The Accounting Review 77(Supplement): 71-105.

Gietzmann MB, Quick R (1998) Capping auditor liability: The German experience. Accounting, Organization and Society 23(1): 81-103.

Glaum M, Lichtblau K, Lindemann J (2004) The extent of earnings management in the U.S. and Germany. Journal of International Accounting Research 3(2): 45-77.

Goergen M, Manjon MC, Renneboog L (2008) Is the German system of corporate governance converging towards the Anglo-American model? Journal of Management \& Governance 12(1): 37-71.

Gregory A, Collier P (1996) Audit fees and auditor change: An investigation of the persistence of fee reduction by type of change. Journal of Business Finance and Accounting 23(1): 13-28.

Gupta PP, Krishnan GV, Yu W (2009) You get what you pay for: An examination of audit quality when audit fee is low. Working Paper.

Hackethal A, Schmidt RH, Tyrell M (2005) Banks and German corporate governance: On the way to a capital market-based system? Corporate Governance - An International Review 13(3): 397-407.

Hay DC, Knechel WR, Wong N (2006) Audit fees: A meta-analysis of the effect of supply and demand attributes. Contemporary Accounting Research 23(1): 141-191.

Heß B, Stefani U (2012) Audit market regulation and supplier concentration around the world: Empirical evidence. Working Paper.

Higgs JL, Skantz TR (2006) Audit and nonaudit fees and the market's reaction to earnings announcements. Auditing: A Journal of Practice \& Theory 25(1): 1-26.

Hitz J-M, Ernstberger J, Stich M (2012) Enforcement of accounting standards in Europe: Empirical evidence for the two-tier mechanism in Germany. European Accounting Review 21(2): 253-281.

Hoitash R, Markelevich A, Barragato CA (2007) Auditor fees and audit quality. Managerial Auditing Journal 22(8): 761-786.

Hribar P, Kraver T, Wilson R (2010) A new measure of accounting quality. Working Paper.

Ireland JC, Lennox CS (2002) The large audit firm fee premium: A case of selectivity bias? Journal of Accounting, Auditing, and Finance 17(1): 73-91.

Joe JR and Vandervelde SD (2007) Do auditor-provided nonaudit services improve audit effectiveness? Contemporary Accounting Research 24(2): 467-487.

Johnson VE, Khurana IK, Reynolds JK (2002) Audit-firm tenure and the quality of financial reports. Contemporary Accounting Research 19(4): 636-660.

Kida T (1980) An investigation into auditors' continuity and related qualification judgments. Journal of Accounting Research 18(2): 506-523.

Kinney WR, Libby R (2002) Discussion of the relation between auditors' fees for non-audit services and earnings management. The Accounting Review 77(Supplement): 107-114. 
Kinney W, Palmrose Z, Scholz S (2004) Auditor independence, non-audit services, and restatements: Was the U.S. Government right? Journal of Accounting Research 42(3): 561-588.

Köhler AG, Marten K-U, Quick R, Ruhnke K (2008) Audit regulation in Germany. Improvements driven by internationalization. Auditing, Trust and Governance. Developing Regulation in Europe. London: Routledge: 111-43.

Köhler AG, Marten K-U, Ratzinger NVS, Wagner M (2010) Prüfungshonorare in Deutschland - Determinanten und Implikationen. Journal of Business Economics (ZfB Zeitschrift für Betriebswirtschaft) 80(1): 5-29.

Kothari SP, Leone AJ, Wasley CE (2001) Performance matched discretionary accrual measures. Journal of Accounting and Economics 39(1): 163-197.

Krause R, Semadeni M (2013) Apprentice, departure, and demotion: An examination of the three types of CEO-board chair separation. Academy of Management Journal 56(3): $805-826$.

La Porta R, Lopez-de-Silanes F, Schleifer A (2006) What works in security laws? The Journal of Finance 61(1): 1-32.

La Porta R, Lopez-de-Silanes F, Schleifer A, Vishny R (1997) Legal determinants of external finance. The Journal of Finance 52(3): 1131-1150.

Lane C (2003) Changes in corporate governance of German corporations: Convergence to the Anglo-American model? Competition \& Change 7(2-3): 79-100.

Larcker DF, Richardson SA (2004) Fees paid to audit firms, accrual choices, and corporate governance. Journal of Accounting Research 42(3): 625-658.

Leuz C, Nanda D, Wysocki PD (2003) Earnings management and investor protection: An international comparison. Journal of Financial Economics 69(3): 505-527.

Lim C-Y, Tan H-T (2008) Non-audit service fees and audit quality: The impact of auditor specialization. Journal of Accouting Research 46(1): 199-246.

McNichols, MF (2000) Research design issues in earnings management studies. Journal of Accounting and Public Policy 19(4-5): 313-345.

Mitra S, Deis DR, Hossain M (2009) The association between audit fees and reported earnings quality in pre-and post-Sarbanes-Oxley regimes. Review of Accounting and Finance 8(3): 232-252.

Mutchler J, Williams D (1990) The relationship between audit technology, client risk profiles, and the going-concern opinion decision. Auditing: A Journal of Practice and Theory 9(3): 39-54.

Palmrose Z-V (1986a) Audit fees and auditor size: Further evidence. Journal of Accounting Research 24(4): 97-110.

Palmrose Z-V (1986b) The effect of nonaudit services on the pricing of audit services: Further evidence. Journal of Accounting Research 24(2): 405-411.

Paterson JS, Valencia A (2011) The effects of recurring on nonrecurring tax, audit-related, and other nonaudit services on auditor independence. Contemporary Accounting Research 28(5): 1510-1536.

Petersen MA (2009) Estimating standard errors in finance panel data sets: Comparing approaches. Review of Financial Studies 22(1): 435-480.

Pratt J, Stice JD (1994) The effects of client characteristics on auditor litigation risk judgments, required audit evidence, and recommended audit fees. The Accounting Review 69(4): 639-656. 
Quick R (2012) EC green paper proposals and audit quality. Accounting in Europe 9(1): 17-38.

Quick R, Sattler M (2011) Beeinträchtigen Beratungsleistungen die Urteilsfähigkeit des Abschlussprüfers? Zum Einfluss von Beratungshonoraren auf diskretionäre Periodenabgrenzungen. Journal of Business Economics (ZfB - Zeitschrift für Betriebswirtschaft) 63(6): 310-343.

Quick R, Warming-Rasmussen BW (2009) Auditor independence and the provision of nonaudit services: Perceptions by German investors. International Journal of Auditing 13(2): 141-162.

Pott C, Mock TJ, Watrin C (2009) Review of empirical research on rotation and non-audit services: Auditor independence in fact vs. appearance, Journal für Betriebswirtschaft 58(4): 209-239.

Ratzinger-Sakel NVS (2013) Auditor fees and auditor independence - Evidence from going concern reporting decisions in Germany. Auditing: A Journal of Practice \& Theory 32(4): 129-168.

Reynolds JK, Deis DR, Francis JR (2004) Professional service fees and auditor objectivity. Auditing: A Journal of Practice \& Theory 23(1): 29-52.

Schneider A, Church BK, Ely KM (2006) Non-audit services and auditor independence: A review of the literature. Journal of Accounting Literature 25: 169-211.

Seibt CH, Wollenschläger B (2011) Dritthaftung des Abschlussprüfers kapitalmarktorientierter Unternehmen. Der Betrieb 24: 1378-1385.

Simon DT, Francis JR (1988) The effects of auditor change on audit fees: Tests of price cutting and price recovery. The Accounting Review 63(2): 255-269.

Simunic DA (1980) The pricing of audit services: Theory and evidence. Journal of Accounting Research 18(1): 161-190.

Simunic DA (1984) Auditing, consulting, and auditor independence. Journal of Accounting Research 22(2): 679-702.

Simunic DA, Stein MT (1996) The impact of litigation risk on audit pricing: A review of the economics and the evidence. Auditing: A Journal of Practice \& Theory 15(Supplement): 119-134.

Srinidhi B, Gul FA (2007) The differential effects of auditors' non-audit and audit fees on accrual quality. Contemporary Accounting Research 24(2): 595-629.

Telberg R (2010) How clients squeeze CPAs on audit fees. CPA Trendlines, November 8.

Turpen RA (1990) Differential pricing on auditors' initial engagements: Further evidence. Auditing: A Journal of Practice \& Theory 9(2): 60-76.

Tuschke A, Sanders WG (2003) Antecedents and consequences of corporate governance reform: The case of Germany. Strategic Management Journal 24(7): 631-649.

Whisenant S, Sankaraguruswamy S, Raghunandan K (2003) Evidence on the joint determination of audit and non-audit fees. Journal of Accounting Research 41(4): 721-744.

Xie Z, Cai C, Ye J (2010) Abnormal audit fees and audit opinion - further evidence from China's capital market. China Journal of Accounting Research 3(1): 51-70.

Wild A (2010) Fee cutting and fee premium of German auditors. DBW (Die Betriebswirtschaft) 70(6): 513-527.

Zmijewski ME (1984) Methodological issues related to the estimation of financial distress prediction models. Journal of Accounting Research 22(Supplement): 59-82. 


\section{Appendix 1}

Variable Definitions

\begin{tabular}{|c|c|}
\hline Variable & Description \\
\hline$|D A 1|$ & - absolute value of discretionary accruals as measured by the Ball and Shivakumar (2006) model. \\
\hline$|D A 2|$ & $\begin{array}{l}\text { - absolute value of discretionary accruals as measured by the Jones (1991) model specification in Dechow (1995) and adjusted for firm } \\
\text { performance by including the ROA variable as suggested by McNichols (2000) and Kothari (2001). }\end{array}$ \\
\hline ABAFEE & - abnormal audit fees estimated from Equation (1). \\
\hline$A G E$ & - number of years since company foundation. \\
\hline BIG5 & $\begin{array}{l}\text { - indicator variable that takes the value of } 1 \text { if the auditor is one of the BIG } 5 \text { audit firms (KPMG, Ernst\&Young, Deloitte, PWC, and BDO), } \\
\text { and } 0 \text { otherwise. }\end{array}$ \\
\hline$B T M$ & - book-to-market ratio (total book value of equity divided by the firms' market capitalization). \\
\hline BUSY & - indicator variable that takes the value of 1 if the fiscal year ends in December, and 0 otherwise. \\
\hline CFO & - cash flow from operations scaled by lagged total assets. \\
\hline CHGLEVE & - leverage change from the prior to the current fiscal year, whereas leverage is defined as long-term liabilities divided by total assets. \\
\hline DPABAFEE & - indicator variable that takes the value of 1 if the abnormal audit fees estimated from Equation (1) are positive, and 0 otherwise. \\
\hline$D A X$ & - indicator variable that takes the value of 1 if the company is listed in the DAX index of the Frankfurt Stock Exchange, and 0 otherwise. \\
\hline$D C F O$ & - indicator variable that takes the value of 1 if the cash flow from operations is negative, and 0 otherwise. \\
\hline FIRST_GCO & - indicator variable that takes the value of 1 if the company received a going-concern modified opinion for the first time, and 0 otherwise. \\
\hline FOREIGN & - ratio of foreign revenue to total revenue. \\
\hline GROWTH & - revenue change from the prior to the current fiscal year. \\
\hline IFRS & - indicator variable that takes the value of 1 if the company applies IFRS for the first time, and 0 otherwise. \\
\hline INITIAL & - indicator variable that takes the value of 1 if the firm's auditor is in the first audit engagement year, and 0 otherwise. \\
\hline ISSUE & - indicator variable that takes the value of 1 if equity titles are issued in the current fiscal year, and 0 otherwise. \\
\hline LAGLOSS & - indicator variable that takes the value of 1 if the prior year's net income is negative, and 0 otherwise. \\
\hline LAGTACC & - prior-year's TACC. \\
\hline LNINVREC & - natural log of inventories and receivables. \\
\hline$L N N F C$ & - natural log of the number of analysts' earnings forecasts. \\
\hline$L N T A$ & - natural log of total assets. \\
\hline LOSS & - indicator variable that takes the value of 1 if the current year's net income is negative, and 0 otherwise. \\
\hline$M B E X$ & $\begin{array}{l}\text { - indicator variable that takes the value of } 1 \text { if the firm meets or beats the earnings expectation (proxied by the most recent median consensus } \\
\text { analyst earnings forecast available on } \mathrm{I} / \mathrm{B} / \mathrm{E} / \mathrm{S} \text { file) by two cents or less, and } 0 \text { otherwise. }\end{array}$ \\
\hline$M D A X$ & - indicator variable that takes the value of 1 if the company is listed in the MDAX index of the Frankfurt Stock Exchange, and 0 otherwise. \\
\hline NAS & - ratio of non-audit fees to total fees. \\
\hline PABAFEE & - positive abnormal audit fees estimated from Equation (1), or respectively, interaction term of ABAFEE and DPABAFEE. \\
\hline$P P E$ & - net property, plant and equipment scaled by lagged total assets. \\
\hline$R E C$ & - accounts receivables scaled by lagged total assets. \\
\hline REPORTLAG & - number of days between the fiscal year-end and the audit opinion date. \\
\hline RESTATE & $\begin{array}{l}\text { - indicator variable that takes the value of } 1 \text { if the client has issued a financial statement restatement for the respective fiscal year, and } 0 \\
\text { otherwise. }\end{array}$ \\
\hline$R E V$ & - total revenues scaled by lagged total assets. \\
\hline$R O A$ & - return on assets (net income divided by total assets). \\
\hline ROE & - return on equity (net income divided by total equity). \\
\hline$S D A X$ & - indicator variable that takes the value of 1 if the company is listed in the SDAX index of the Frankfurt Stock Exchange, and 0 otherwise. \\
\hline STDFC & - standard deviation of analysts' earnings forecasts. \\
\hline$T A$ & - total assets. \\
\hline TACC & - total accruals (net income minus cash flows from operations) scaled by lagged total assets. \\
\hline TECDAX & - indicator variable that takes the value of 1 if the company is listed in the TECDAX index of the Frankfurt Stock Exchange, and 0 otherwise. \\
\hline ZSCORE & - Zmijewski's (1984) financial condition index. \\
\hline
\end{tabular}


Table 1

Results of Empirical Studies Investigating the Association between Abnormal Audit Fees and Audit Quality

\begin{tabular}{|c|c|c|c|c|c|}
\hline Study (by year) & Country & $\begin{array}{l}\text { Sample } \\
\text { Period }\end{array}$ & $\begin{array}{l}\text { Sample } \\
\text { Size }\end{array}$ & $\begin{array}{l}\text { Audit Quality Measure } \\
\text { (Main Analyses) }\end{array}$ & Results \\
\hline \multicolumn{6}{|l|}{$\underline{\text { Journal Publications }}$} \\
\hline Eshleman and Guo (forthcoming) & US & $2000-2011$ & 4,476 & $\begin{array}{c}\text { Discretionary accruals } \\
\text { Analysts' earnings forecasts }\end{array}$ & Abnormal audit fees are positively associated with audit quality. \\
\hline Asthana and Boone (2012) & US & $2000-2009$ & 18,873 & $\begin{array}{l}\text { Discretionary accruals } \\
\text { Analysts' earnings forecasts }\end{array}$ & Positive and negative abnormal audit fees are negatively associated with audit quality. \\
\hline Blankley et al. (2012) & US & $2004-2007$ & 5,978 & Financial restatement & Positive abnormal audit fees are positively associated with audit quality. \\
\hline Choi et al. (2010) & US & $2000-2003$ & 9,815 & Discretionary accruals & $\begin{array}{l}\text { Positive abnormal audit fees are negatively associated with audit quality. Negative abnormal audit } \\
\text { fees are not significantly associated with audit quality. }\end{array}$ \\
\hline Xie et al. (2010) & China & $2002-2008$ & 7,028 & Audit opinion quality & Abnormal audit fees are generally not associated with audit quality. \\
\hline Mitra et al. (2009) & US & $2000-2005$ & 6,852 & Discretionary accruals & Expected and unexpected audit fees are both positively associated with audit quality. \\
\hline Hoitash et al. (2007) & US & $2000-2003$ & 7,968 & $\begin{array}{l}\text { Discretionary accruals } \\
\text { Accrual estimation error metric }\end{array}$ & $\begin{array}{l}\text { Abnormal total fees are negatively associated with audit quality. The results for abnormal audit and } \\
\text { non-audit fees are insignificant. }\end{array}$ \\
\hline Higgs and Skantz (2006) & US & $2001-2002$ & 2,626 & Earnings response coefficient & $\begin{array}{l}\text { Abnormal total and audit fees are positively associated with audit quality. The results for abnormal } \\
\text { non-audit fees are inconsistent. }\end{array}$ \\
\hline \multicolumn{6}{|l|}{ Working Papers } \\
\hline Hribar et al. (2010) & US & $2000-2007$ & 25,415 & $\begin{array}{c}\text { Fraud incident } \\
\text { Financial restatement } \\
\text { SEC comment letter }\end{array}$ & Unexpected audit fees are negatively associated with audit quality. \\
\hline Gupta et al. (2009) & US & $2000-2006$ & 23,372 & $\begin{array}{l}\text { Going-concern audit opinion } \\
\text { Abnormal discretionary accruals } \\
\text { Other audit quality measures }\end{array}$ & $\begin{array}{l}\text { Negative abnormal audit fees are negatively associated with audit quality. Positive abnormal audit } \\
\text { fees are not significantly associated with audit quality. }\end{array}$ \\
\hline
\end{tabular}




\section{Table 2}

\section{Sample Description}

Panel A: Sample Selection Process

\begin{tabular}{|c|c|c|}
\hline Sample Selection Steps & Firm-Years & Firms \\
\hline $\begin{array}{l}\text { Audited Annual Reports Collected - } \\
\text { for firms having IFRS financial information available in the } \\
\text { Thomson Reuters Worldscope database (2005 trough 2010); } \\
\text { excluding SIC Codes 6000-6999 }\end{array}$ & 2,704 & 607 \\
\hline less: Missing Audit Fee Disclosures & 137 & \\
\hline $\begin{array}{l}\text { less: International Audit Fee Disclosures - } \\
\text { (i.e., missing a separate disclosure for the German audit firm) }\end{array}$ & 86 & \\
\hline less: Shortened Fiscal Year & 17 & \\
\hline less: Joint Audits & 14 & \\
\hline less: Reporting Irregularities & 12 & \\
\hline less: Missing Control Variables - Equation (1) and (4) & 104 & \\
\hline Final Study Sample & 2,334 & 537 \\
\hline \multicolumn{3}{|l|}{ Panel B: Audit Fee Observations by Year } \\
\hline Year & Firm-Years & $\%$ \\
\hline 2005 & 320 & $13 \%$ \\
\hline 2006 & 393 & $17 \%$ \\
\hline 2007 & 415 & $18 \%$ \\
\hline 2008 & 418 & $18 \%$ \\
\hline 2009 & 393 & $17 \%$ \\
\hline 2010 & 395 & $17 \%$ \\
\hline
\end{tabular}

Panel C: Audit Fee Observations by Industry

\begin{tabular}{lcc}
\hline Industry Classification & Firm-Years & $\%$ \\
\hline Agriculture (SIC Codes 0100-0999) & 14 & $1 \%$ \\
Mining and construction (SIC Codes 1000-1999, excl. 1300-1399) & 63 & $3 \%$ \\
Consumer manufactures (SIC Codes 2000-2111, 2200-2799) & 217 & $9 \%$ \\
Chemicals, pharma and refining (SIC Codes 1300-1399, 2800- & 155 & $7 \%$ \\
2824, 2830-2836, 2840-2899, 2900-2999) & & $32 \%$ \\
Durable manufactures (SIC Codes 3000-3999, excl. 3570-3579 & 735 \\
and 3670-3679) & 117 \\
Transportation (SIC Codes 4000-4899) & $5 \%$ \\
Utilities (SIC Codes 4900-4999) & 80 & $3 \%$ \\
Retail (SIC Codes 5000-5999) & 142 & $6 \%$ \\
Services (SIC Codes 7000-8999, excl. 7370-7379) & 338 & $14 \%$ \\
Computers (SIC Codes 3570-3579, 3670-3679, 7370-7379) & 473 & $20 \%$ \\
\hline
\end{tabular}

Table 2, Panel A exhibits the sample selection process taken to derive the final study sample. Please note that the audited annual reports were only collected for those firms that have IFRS (consolidated) financial information available in the Thomson Reuters Worldscope database for the period from 2005 through 2010. Panel B (Panel C) reports the distribution of the audit fee sample by year (by industry). 
Table 3

Descriptive Statistics

\begin{tabular}{|c|c|c|c|c|c|c|c|c|}
\hline Continuous Variables & Mean & Std. Dev. & Min & Q1 & Median & Q3 & Max & Firm-Years \\
\hline$|D A 1|$ & 0.07806 & 0.10176 & 0.00000 & 0.02001 & 0.04653 & 0.09453 & 1.24504 & 2,334 \\
\hline$|D A 2|$ & 0.10021 & 0.12465 & 0.00006 & 0.02816 & 0.06027 & 0.12247 & 1.14538 & 2,334 \\
\hline LNFEE & 5.24938 & 1.11786 & 3.21888 & 4.44265 & 5.10595 & 5.84064 & 8.93590 & 2,334 \\
\hline ABAFEE & 0.00000 & 0.47581 & -2.48909 & -0.29646 & 0.03031 & 0.31294 & 1.83583 & 2,334 \\
\hline LNTA & 12.04178 & 2.01842 & 7.48549 & 10.68329 & 11.74489 & 13.13047 & 18.42288 & 2,334 \\
\hline$L N S E G$ & 1.10394 & 0.65535 & 0.00000 & 0.69315 & 1.38629 & 1.60944 & 2.39790 & 2,334 \\
\hline LNINVREC & -1.04977 & 0.92613 & -4.21720 & -1.47677 & -0.91883 & -0.57947 & 2.20013 & 2,334 \\
\hline CHGLEVE & 0.00453 & 0.13744 & -0.55120 & -0.03943 & -0.00211 & 0.03899 & 0.64201 & 2,334 \\
\hline ZSCORE & -1.11182 & 1.87484 & -4.86921 & -2.22521 & -1.15451 & -0.32141 & 7.82267 & 2,334 \\
\hline GROWTH & 0.11953 & 0.50211 & -0.83424 & -0.04618 & 0.05807 & 0.17285 & 4.14211 & 2,334 \\
\hline$R O E$ & 0.07850 & 0.56849 & -2.58886 & -0.01105 & 0.09003 & 0.19058 & 3.32768 & 2,334 \\
\hline$B T M$ & 0.71841 & 0.64196 & -1.08508 & 0.35545 & 0.59948 & 0.94937 & 3.14047 & 2,334 \\
\hline$N A S$ & 0.25275 & 0.19919 & 0.00000 & 0.07658 & 0.23156 & 0.39773 & 0.75124 & 2,334 \\
\hline REPORTLAG & 90.35604 & 40.92944 & 19.00 & 68.00 & 83.00 & 106.00 & 308.00 & 2,334 \\
\hline$C F O$ & 0.09508 & 0.24802 & -0.93577 & 0.01453 & 0.07729 & 0.13780 & 1.35109 & 2,334 \\
\hline LAGTACC & -0.08185 & 0.22633 & -1.61129 & -0.10430 & -0.04326 & 0.00246 & 0.38947 & 2,334 \\
\hline Indicator Variables & Mean & Std. Dev. & $\mathbf{0}$ & 1 & Firm-Years & & & \\
\hline DPABAFEE & 0.52142 & 0.49965 & 1,117 & 1,217 & 2,334 & & & \\
\hline FOREIGN & 0.62339 & 0.48464 & 879 & 1,455 & 2,334 & & & \\
\hline LOSS & 0.26907 & 0.44357 & 1,706 & 628 & 2,334 & & & \\
\hline LAGLOSS & 0.26992 & 0.44401 & 1,704 & 630 & 2,334 & & & \\
\hline ISSUE & 0.29820 & 0.45757 & 1,638 & 696 & 2,334 & & & \\
\hline BIG5 & 0.64439 & 0.47880 & 830 & 1,504 & 2,334 & & & \\
\hline INITIAL & 0.12039 & 0.32549 & 2,053 & 281 & 2,334 & & & \\
\hline$B U S Y$ & 0.87875 & 0.32649 & 283 & 2,051 & 2,334 & & & \\
\hline IFRS & 0.08226 & 0.27482 & 2,142 & 192 & 2,334 & & & \\
\hline
\end{tabular}

Table 3 exhibits the summary statistics of the main variables used in our analysis. The audit (non-audit) fee data and the BIG5 indicator variable were handcollected. The data for all other variables were taken from the Thomson Reuters Worldscope database. All variables are defined in Appendix 1. 
Table 4

Pearson-Spearman Correlations among Regression Variables

\begin{tabular}{|c|c|c|c|c|c|c|c|c|c|c|c|c|c|c|c|}
\hline & $|D A 1|$ & $|D A 2|$ & ABAFEE & LNTA & $A G E$ & $B T M$ & GROWTH & ISSUE & $C F O$ & LOSS & CHGLEVE & ZSCORE & BIG5 & INITIAL & LAGTACC \\
\hline \multirow{2}{*}{$|D A 1|$} & \multirow{2}{*}{1.0000} & 0.4517 & 0.0229 & -0.1136 & -0.0580 & -0.1580 & -0.0089 & 0.0818 & -0.0156 & 0.2622 & 0.0806 & 0.0899 & -0.0267 & 0.0247 & -0.0961 \\
\hline & & $(0.00)$ & $(0.27)$ & $(0.00)$ & $(0.01)$ & $(0.00)$ & $(0.67)$ & $(0.00)$ & $(0.45)$ & $(0.00)$ & $(0.00)$ & $(0.00)$ & $(0.20)$ & $(0.23)$ & $(0.00)$ \\
\hline \multirow{2}{*}{$|D A 2|$} & 0.5951 & \multirow{2}{*}{1.0000} & -0.0097 & 0.0136 & -0.0575 & -0.1095 & 0.0256 & 0.0657 & 0.0011 & 0.1380 & 0.0727 & 0.1205 & 0.0216 & 0.0030 & -0.0892 \\
\hline & $(0.00)$ & & $(0.64)$ & $(0.51)$ & $(0.01)$ & $(0.00)$ & $(0.22)$ & $(0.00)$ & $(0.96)$ & $(0.00)$ & $(0.00)$ & $(0.00)$ & $(0.30)$ & $(0.88)$ & $(0.00)$ \\
\hline \multirow{2}{*}{ ABAFEE } & 0.0075 & -0.0082 & \multirow{2}{*}{$\begin{array}{l}(0.04) \\
1.0000\end{array}$} & 0.0048 & 0.0402 & -0.0247 & -0.0346 & 0.0038 & 0.0587 & 0.0209 & -0.0342 & 0.0104 & 0.0007 & -0.0043 & -0.0494 \\
\hline & $(0.72)$ & $(0.69)$ & & $(0.82)$ & $(0.05)$ & $(0.23)$ & $(0.09)$ & $(0.85)$ & $(0.00)$ & $(0.31)$ & $(0.10)$ & $(0.62)$ & $(0.97)$ & $(0.84)$ & $(0.02)$ \\
\hline \multirow{2}{*}{ LNTA } & 0.0277 & 0.1782 & 0.0000 & \multirow{2}{*}{1.0000} & 0.3144 & -0.0441 & 0.0737 & 0.0069 & 0.2559 & -0.2493 & -0.0479 & 0.1554 & 0.3902 & -0.1012 & -0.0713 \\
\hline & $(0.18)$ & $(0.00)$ & $(1.00)$ & & $(0.00)$ & $(0.03)$ & $(0.00)$ & $(0.74)$ & $(0.00)$ & $(0.00)$ & $(0.02)$ & $(0.00)$ & $(0.00)$ & $(0.00)$ & $(0.00)$ \\
\hline \multirow{2}{*}{$A G E$} & -0.0501 & -0.0155 & 0.0265 & 0.3535 & \multirow{2}{*}{1.0000} & 0.0259 & -0.1054 & -0.1352 & 0.0558 & -0.0918 & -0.0653 & 0.1759 & 0.1420 & -0.0358 & 0.0036 \\
\hline & $(0.02)$ & $(0.46)$ & $(0.20)$ & $(0.00)$ & & $(0.21)$ & $(0.00)$ & $(0.00)$ & $(0.01)$ & $(0.00)$ & $(0.00)$ & $(0.00)$ & $(0.00)$ & $(0.08)$ & $(0.86)$ \\
\hline \multirow{2}{*}{$B T M$} & -0.1411 & -0.1016 & 0.0000 & -0.0468 & 0.0076 & \multirow{2}{*}{1.0000} & -0.1549 & -0.1863 & -0.1490 & 0.0062 & -0.0311 & -0.1624 & -0.0599 & -0.0107 & 0.0800 \\
\hline & $(0.00)$ & $(0.00)$ & $(1.00)$ & $(0.02)$ & $(0.71)$ & & $(0.00)$ & $(0.00)$ & $(0.00)$ & $(0.77)$ & $(0.13)$ & $(0.00)$ & $(0.00)$ & $(0.61)$ & $(0.00)$ \\
\hline \multirow{2}{*}{ GROWTH } & 0.0397 & 0.0895 & 0.0000 & -0.0284 & -0.0681 & -0.0661 & \multirow{2}{*}{1.0000} & 0.1614 & 0.1783 & -0.2881 & 0.0656 & -0.1710 & 0.0159 & -0.0131 & 0.0827 \\
\hline & $(0.06)$ & $(0.00)$ & $(1.00)$ & $(0.17)$ & $(0.00)$ & $(0.00)$ & & $(0.00)$ & $(0.00)$ & $(0.00)$ & $(0.00)$ & $(0.00)$ & $(0.44)$ & $(0.53)$ & $(0.00)$ \\
\hline \multirow{2}{*}{ ISSUE } & 0.1013 & 0.0958 & 0.0000 & 0.0157 & -0.1225 & -0.1672 & 0.1593 & \multirow{2}{*}{1.0000} & -0.0938 & 0.0712 & -0.0387 & 0.0190 & 0.0029 & 0.0035 & 0.0300 \\
\hline & $(0.00)$ & $(0.00)$ & $(1.00)$ & $(0.45)$ & $(0.00)$ & $(0.00)$ & $(0.00)$ & & $(0.00)$ & $(0.00)$ & $(0.06)$ & $(0.36)$ & $(0.89)$ & $(0.87)$ & $(0.15)$ \\
\hline \multirow{2}{*}{ CFO } & 0.1150 & 0.2391 & 0.0542 & 0.5007 & 0.1081 & -0.0533 & -0.0086 & -0.0873 & \multirow{2}{*}{1.0000} & -0.4434 & -0.1383 & -0.2827 & 0.1419 & -0.0870 & -0.1629 \\
\hline & $(0.00)$ & $(0.00)$ & $(0.01)$ & $(0.00)$ & $(0.00)$ & $(0.01)$ & $(0.68)$ & $(0.00)$ & & $(0.00)$ & $(0.00)$ & $(0.00)$ & $(0.00)$ & $(0.00)$ & $(0.00)$ \\
\hline \multirow{2}{*}{ LOSS } & 0.2125 & 0.0992 & 0.0417 & -0.2451 & -0.0774 & 0.0367 & -0.1255 & 0.0712 & -0.3323 & \multirow{2}{*}{1.0000} & 0.3063 & 0.4084 & -0.0538 & 0.0932 & -0.0586 \\
\hline & $(0.00)$ & $(0.00)$ & $(0.04)$ & $(0.00)$ & $(0.00)$ & $(0.08)$ & $(0.00)$ & $(0.00)$ & $(0.00)$ & & $(0.00)$ & $(0.00)$ & $(0.01)$ & $(0.00)$ & $(0.00)$ \\
\hline \multirow{2}{*}{ CHGLEVE } & 0.1209 & 0.0450 & 0.0000 & -0.1004 & -0.0574 & $\begin{array}{l}-0.1261 \\
\end{array}$ & 0.0689 & -0.0315 & -0.1696 & 0.2654 & \multirow{2}{*}{1.0000} & 0.2711 & -0.0290 & 0.0253 & 0.0275 \\
\hline & $(0.00)$ & $(0.03)$ & $(1.00)$ & $(0.00)$ & $(0.01)$ & $(0.00)$ & $(0.00)$ & $(0.13)$ & $(0.00)$ & $(0.00)$ & & $(0.00)$ & $(0.16)$ & $(0.22)$ & $(0.18)$ \\
\hline \multirow{2}{*}{ ZSCORE } & 0.2325 & 0.1825 & 0.0000 & 0.0055 & 0.1244 & -0.2835 & -0.0600 & 0.0546 & -0.2236 & 0.4378 & 0.3991 & \multirow{2}{*}{1.0000} & 0.0417 & 0.0644 & -0.1320 \\
\hline & $(0.00)$ & $(0.00)$ & $(1.00)$ & $(0.79)$ & $(0.00)$ & $(0.00)$ & $(0.00)$ & $(0.01)$ & $(0.00)$ & $(0.00)$ & $(0.00)$ & & $(0.04)$ & $(0.00)$ & $(0.00)$ \\
\hline \multirow{2}{*}{ BIG5 } & -0.0160 & 0.0271 & 0.0000 & 0.3851 & 0.1529 & -0.0610 & -0.0181 & 0.0029 & 0.1635 & -0.0538 & -0.0399 & 0.0023 & \multirow{2}{*}{1.0000} & -0.0607 & -0.0969 \\
\hline & $(0.44)$ & $(0.19)$ & $(1.00)$ & $(0.00)$ & $(0.00)$ & $(0.00)$ & $(0.38)$ & $(0.89)$ & $(0.00)$ & $(0.01)$ & $(0.05)$ & $(0.91)$ & & $(0.00)$ & $(0.00)$ \\
\hline & 0.0223 & -0.0004 & 0.0000 & -0.1036 & -0.0259 & 0.0002 & 0.0048 & 0.0035 & -0.0622 & 0.0923 & 0.0286 & 0.0656 & -0.0607 & & -0.0008 \\
\hline INITIAL & $(0.28)$ & $(0.98)$ & $(1.00)$ & $(0.00)$ & $(0.21)$ & $(0.99)$ & $(0.82)$ & $(0.87)$ & $(0.00)$ & $(0.00)$ & $(0.17)$ & $(0.00)$ & $(0.00)$ & 1.0000 & $(0.97)$ \\
\hline & -0.2811 & -0.3095 & 0.0009 & -0.2761 & -0.0210 & 0.1151 & 0.0668 & -0.0170 & -0.4126 & -0.0175 & 0.0716 & -0.1585 & -0.0871 & 0.0178 & \\
\hline LAGTACC & $(0.00)$ & $(0.00)$ & $(0.97)$ & $(0.00)$ & $(0.31)$ & $(0.00)$ & $(0.00)$ & $(0.41)$ & $(0.00)$ & $(0.40)$ & $(0.00)$ & $(0.00)$ & $(0.00)$ & $(0.39)$ & 1.0000 \\
\hline
\end{tabular}

Pearson correlation coefficients are shown below the diagonal while Spearman correlation coefficients are shown above the diagonal. Two-tailed p-values are presented in parentheses. All variables are defined in Appendix 1. 
Table 5

Results for the Model of Abnormal Audit Fees

\begin{tabular}{|c|c|c|c|}
\hline Equation No. & & \multicolumn{2}{|l|}{1} \\
\hline Dependent Variable & & \multicolumn{2}{|c|}{ LNFEE } \\
\hline Variables & expected sign & Coefficient & t-statistics \\
\hline LNTA & + & $0.44227 * * *$ & 22.78 \\
\hline LNSEG & + & 0.05222 & 1.76 \\
\hline LNINVREC & + & 0.03188 & 1.01 \\
\hline FOREIGN & + & 0.07118 & 0.87 \\
\hline$L A G L O S S$ & + & $0.12259 * * *$ & 3.48 \\
\hline CHGLEVE & + & $0.24052 * *$ & 2.28 \\
\hline ZSCORE & + & $0.06001 * * *$ & 6.52 \\
\hline GROWTH & $+/-$ & $-0.10449 * *$ & -3.14 \\
\hline$R O E$ & - & 0.03247 & 1.43 \\
\hline BTM & $+/-$ & -0.01552 & -0.62 \\
\hline ISSUE & $+/-$ & 0.02283 & 0.67 \\
\hline BIG5 & + & $0.11561 * * *$ & 4.27 \\
\hline INITIAL & - & $-0.13204 * * *$ & -3.82 \\
\hline$N A S$ & $+/-$ & $-0.21006 * *$ & -3.08 \\
\hline REPORTLAG & + & 0.00049 & 1.39 \\
\hline$B U S Y$ & + & 0.02775 & 0.60 \\
\hline IFRS & + & 0.06348 & 1.59 \\
\hline$D A X$ & + & $0.61071 * * *$ & 5.44 \\
\hline$M D A X$ & + & $0.24333 * *$ & 2.76 \\
\hline$S D A X$ & + & $0.09102 *$ & 1.92 \\
\hline$T E C D A X$ & + & $0.18646 * * *$ & 4.19 \\
\hline Firm Years & & 2,334 & \\
\hline Adj. $R^{2}$ & & 0.8188 & \\
\hline
\end{tabular}

This table shows the coefficients and t-statistics for estimating Equation (1) as an ordinary least square regression that includes fixed effects for fiscal year and industry. The analysis employs heteroskedasticity-adjusted robust standard errors clustered by firm. The regression is estimated with an intercept included (not tabulated). $* * *, * *$, and $*$ denote $p$-value significance at the $1 \%, 5 \%$ and $10 \%$ levels, with two-tailed tests. All variables are defined in Appendix 1. 


\section{Table 6}

Results on the Association between Abnormal Audit Fees and Discretionary Accruals

\begin{tabular}{|c|c|c|c|c|c|}
\hline \multirow{3}{*}{$\begin{array}{c}\text { Dependent Variable } \\
\text { Variables }\end{array}$} & \multirow[b]{3}{*}{ expected sign } & \multicolumn{2}{|l|}{4} & \multicolumn{2}{|l|}{4} \\
\hline & & \multicolumn{2}{|c|}{$|D A 1|$} & \multicolumn{2}{|l|}{$|D A 2|$} \\
\hline & & Coefficient & t-statistics & Coefficient & t-statistics \\
\hline ABAFEE & $+/-$ & -0.00751 & -0.65 & -0.01486 & -1.01 \\
\hline DPABAFEE & $+/-$ & -0.00731 & -1.47 & $-0.01952 * *$ & -2.24 \\
\hline PABAFEE & $+/$ & $0.02570 * *$ & 2.96 & $0.05375 * * *$ & 2.64 \\
\hline LNTA & - & -0.00171 & -0.88 & 0.00362 & 1.28 \\
\hline$A G E$ & - & $-0.00008 *$ & -1.89 & $-0.00014 * *$ & -2.34 \\
\hline BTM & $+/$ & $-0.01035 * *$ & -2.53 & -0.00373 & -0.74 \\
\hline GROWTH & $+/$ & 0.01273 & 1.52 & $0.02818 * * *$ & 3.00 \\
\hline ISSUE & $+/$ & $0.01271 *$ & 1.83 & $0.01609 * *$ & 2.53 \\
\hline$C F O$ & $+/$ & $0.06291 * * *$ & 4.33 & $0.10647 * * *$ & 3.27 \\
\hline LOSS & + & $0.04342 * * *$ & 7.37 & $0.03318 * * *$ & 4.67 \\
\hline CHGLEVE & + & 0.02829 & 1.10 & -0.01435 & -0.45 \\
\hline ZSCORE & + & $0.00712 *$ & 2.19 & $0.01088 * * *$ & 4.11 \\
\hline BIG5 & - & $-0.00806 * *$ & -2.74 & $-0.01453 * *$ & -2.14 \\
\hline INITIAL & + & -0.00016 & -0.03 & -0.00186 & -0.24 \\
\hline$L A G T A C C$ & $+/-$ & $-0.09430 * *$ & -3.19 & $-0.09759 * * *$ & -2.95 \\
\hline Firm Years & & \multicolumn{2}{|l|}{2,334} & \multicolumn{2}{|l|}{2,334} \\
\hline Adj. $\mathbf{R}^{2}$ & & \multicolumn{2}{|c|}{0.1855} & \multicolumn{2}{|l|}{0.2140} \\
\hline
\end{tabular}

This table shows the coefficients and $t$-statistics for estimating Equation (4) for $|D A 1|$ and $|D A 2|$, respectively, as ordinary least square regressions that include fixed effects for fiscal year and industry. The analyses employ heteroskedasticity-adjusted robust standard errors clustered by firm. The regressions are estimated with an intercept included (not tabulated). ***, **, and * denote p-value significance at the 1\%, 5\% and $10 \%$ levels, with two-tailed tests. All variables are defined in Appendix 1. 
Table 7

Sensitivity Analyses on the Association between Different Threshold Levels of Abnormal Audit Fees and $|D A 1|$

\begin{tabular}{|c|c|c|c|c|c|c|c|c|c|}
\hline Equation No. & & \multicolumn{2}{|l|}{4} & \multicolumn{2}{|l|}{4} & \multicolumn{2}{|l|}{4} & \multicolumn{2}{|l|}{4} \\
\hline Dependent Variable & & \multicolumn{2}{|c|}{$|D A 1|$} & \multicolumn{2}{|c|}{$|D A 1|$} & \multicolumn{2}{|l|}{$|D A 1|$} & \multicolumn{2}{|l|}{$|D A 1|$} \\
\hline Variable of Interest - Definition & & \multicolumn{2}{|c|}{$P A B A F E E \geq 1 \%$} & \multicolumn{2}{|c|}{$P A B A F E E \geq 2 \%$} & \multicolumn{2}{|c|}{ PABAFEE $\geq 5 \%$} & \multicolumn{2}{|c|}{ PABAFEE $\geq 10 \%$} \\
\hline Variables & expected sign & Coefficient & t-statistics & Coefficient & t-statistics & Coefficient & t-statistics & Coefficient & t-statistics \\
\hline ABAFEE & $+/$ & -0.01280 & 1.17 & -0.01581 & -1.48 & -0.00726 & -0.87 & -0.00537 & -0.84 \\
\hline DPABAFEE & $+/$ & -0.00256 & -0.54 & 0.00313 & 0.61 & -0.00912 & -1.39 & -0.01575 & -0.99 \\
\hline PABAFEE & +/ & $0.02856 * * *$ & 3.60 & $0.02516 * * *$ & 3.78 & $0.02717 * * *$ & 4.10 & $0.04143 *$ & 1.84 \\
\hline$L N T A$ & - & -0.00203 & -1.12 & -0.00196 & -1.07 & -0.00197 & -1.10 & -0.00181 & -0.98 \\
\hline$A G E$ & - & $-0.00008 *$ & -1.98 & $-0.00008 *$ & -1.98 & $-0.00008 *$ & -2.02 & $-0.00008 *$ & -2.04 \\
\hline$B T M$ & $+/$ & $-0.01027 * *$ & -3.13 & $-0.01020 * *$ & -3.12 & $-0.01022 * *$ & -3.13 & $-0.01018 * *$ & -3.07 \\
\hline GROWTH & + & 0.01229 & 1.44 & 0.01244 & 1.45 & 0.01231 & 1.44 & 0.01235 & 1.43 \\
\hline ISSUE & + & $0.01503 * *$ & 2.52 & $0.01502 * *$ & 2.49 & $0.01502 * *$ & 2.56 & $0.01501 * *$ & 2.59 \\
\hline CFO & $+/$ & $0.06467 * * *$ & 4.51 & $0.06485 * * *$ & 4.59 & $0.06433 * * *$ & 4.52 & $0.06402 * * *$ & 4.51 \\
\hline LOSS & + & $0.04335 * * *$ & 8.14 & $0.04354 * * *$ & 8.28 & $0.04305 * * *$ & 8.21 & $0.04292 * * *$ & 8.17 \\
\hline CHGLEVE & + & 0.03462 & 1.38 & 0.03497 & 1.41 & 0.03458 & 1.37 & 0.03451 & 1.37 \\
\hline ZSCORE & + & $0.00640 *$ & 1.93 & $0.00638 *$ & 1.92 & $0.00644 *$ & 1.93 & $0.00649 *$ & 1.94 \\
\hline BIG5 & - & $-0.00617 *$ & -2.10 & $-0.00614 *$ & -2.16 & -0.00637 * & -2.15 & $-0.00638 *$ & -2.14 \\
\hline INITIAL & + & 0.00042 & 0.07 & 0.00044 & 0.07 & 0.00036 & 0.06 & 0.00036 & 0.06 \\
\hline LAGTACC & + & $-0.09309 * *$ & -3.21 & $-0.09330 * * *$ & -3.22 & $-0.09309 * *$ & -3.20 & $-0.09310 * *$ & -3.20 \\
\hline Firm Years & & \multicolumn{2}{|l|}{2,334} & \multicolumn{2}{|l|}{2,334} & \multicolumn{2}{|l|}{2,334} & \multicolumn{2}{|l|}{2,334} \\
\hline Adj. $R^{2}$ & & \multicolumn{2}{|c|}{0.1713} & \multicolumn{2}{|c|}{0.1715} & \multicolumn{2}{|l|}{0.1707} & \multicolumn{2}{|l|}{0.1706} \\
\hline
\end{tabular}

This table shows the coefficients and t-statistics for estimating Equation (4) for $\mid$ DA1 | and different threshold levels of positive abnormal audit fees (see above) as ordinary least square regressions that include fixed effects for fiscal year and industry. The analyses employ heteroskedasticity-adjusted robust standard errors clustered by firm. The regressions are estimated with an intercept included (not tabulated). ***,**, and * denote pvalue significance at the $1 \%, 5 \%$ and $10 \%$ levels, with two-tailed tests. All variables are defined in Appendix 1. 
Table 8

Sensitivity Analyses on the Association between Different Threshold Levels of Abnormal Audit Fees and |DA2|

\begin{tabular}{|c|c|c|c|c|c|c|c|c|c|}
\hline Equation No. & & \multicolumn{2}{|l|}{4} & \multicolumn{2}{|l|}{4} & \multicolumn{2}{|l|}{4} & \multicolumn{2}{|l|}{4} \\
\hline Dependent Variable & & \multicolumn{2}{|l|}{$|D A 2|$} & \multicolumn{2}{|c|}{$|D A 2|$} & \multicolumn{2}{|c|}{$|D A 2|$} & \multicolumn{2}{|l|}{$|D A 2|$} \\
\hline Variable of Interest & \multirow[b]{2}{*}{ expected sign } & \multicolumn{2}{|c|}{$P A B A F E E \geq 1 \%$} & \multicolumn{2}{|c|}{$P A B A F E E \geq 2 \%$} & \multicolumn{2}{|c|}{$P A B A F E E \geq 5 \%$} & \multicolumn{2}{|c|}{ PABAFEE $\geq 10 \%$} \\
\hline Variables & & Coefficient & t-statistics & Coefficient & t-statistics & Coefficient & t-statistics & Coefficient & t-statistics \\
\hline ABAFEE & $+/$ & -0.02061 & -1.43 & $-0.02349 *$ & -1.82 & $-0.02141 * *$ & -1.99 & $-0.01959 * *$ & -2.38 \\
\hline DPABAFEE & $+/-$ & $-0.01651 *$ & -1.74 & -0.01492 & -1.52 & $-0.02531 * *$ & -2.09 & -0.02638 & -0.89 \\
\hline PABAFEE & $+/$ & $0.06037 * * *$ & 2.96 & $0.06336 * * *$ & 3.02 & $0.07458 * * *$ & 3.11 & $0.07512 *$ & 1.86 \\
\hline LNTA & - & $0.00478 *$ & 1.83 & $0.00476 *$ & 1.82 & $0.00475 *$ & 1.83 & $0.00525 * *$ & 2.01 \\
\hline$A G E$ & - & $-0.00016 * * *$ & -2.70 & $-0.00015 * * *$ & -2.68 & $-0.00016^{* * *}$ & -2.70 & $-0.00016 * * *$ & -2.73 \\
\hline BTM & $+/-$ & -0.00251 & -0.53 & -0.00239 & -0.50 & -0.00232 & -0.49 & -0.00227 & -0.48 \\
\hline GROWTH & $+/$ & $0.02733 * * *$ & 2.95 & $0.02738 * * *$ & 2.69 & $0.02734 * * *$ & 2.96 & $0.02732 * * *$ & 2.94 \\
\hline ISSUE & $+/$ & $0.01751 * * *$ & 2.68 & $0.01750 * * *$ & 2.69 & $0.01734 * * *$ & 2.67 & $0.01719 * * *$ & 2.63 \\
\hline CFO & $+/$ & $0.10931 * * *$ & 3.40 & $0.10951^{* * *}$ & 3.41 & $0.10891 * * *$ & 3.40 & $0.10781 * * *$ & 3.37 \\
\hline LOSS & + & $0.03540 * * *$ & 4.93 & $0.03568 * * *$ & 5.00 & $0.03531 * * *$ & 4.98 & $0.03495 * * *$ & 4.94 \\
\hline CHGLEVE & + & -0.00580 & -0.18 & -0.00538 & -0.17 & -0.00504 & -0.16 & -0.00540 & -0.17 \\
\hline ZSCORE & + & $0.01020 * * *$ & 3.87 & $0.01015 * * *$ & 3.85 & $0.01013^{* * *}$ & 3.85 & $0.01025 * * *$ & 3.89 \\
\hline BIG5 & - & -0.00975 & -1.48 & -0.00966 & -1.47 & -0.00971 & -1.48 & -0.00960 & -1.47 \\
\hline INITIAL & + & -0.00106 & -0.14 & -0.00097 & -0.13 & -0.00122 & -0.16 & -0.00125 & -0.16 \\
\hline LAGTACC & $+/$ & $-0.09872 * * *$ & -3.04 & $-0.09888 * * *$ & -3.04 & $-0.09946 * * *$ & -3.08 & $-0.09951 * * *$ & -3.05 \\
\hline Firm Years & & \multicolumn{2}{|l|}{2,334} & \multicolumn{2}{|c|}{2,334} & \multicolumn{2}{|c|}{2,334} & \multicolumn{2}{|l|}{2,334} \\
\hline Adj. $\mathbf{R}^{2}$ & & \multicolumn{2}{|c|}{0.1872} & \multicolumn{2}{|c|}{0.1868} & \multicolumn{2}{|c|}{0.1871} & \multicolumn{2}{|l|}{0.1871} \\
\hline
\end{tabular}

This table shows the coefficients and t-statistics for estimating Equation (4) for $|D A 2|$ and different threshold levels of positive abnormal audit fees (see above) as ordinary least square regressions that include fixed effects for fiscal year and industry. The analyses employ heteroskedasticity-adjusted robust standard errors clustered by firm. The regressions are estimated with an intercept included (not tabulated). ***, **, and * denote $p$ - 
Table 9

Results on the Association between Abnormal Audit Fees and Alternative Audit Quality Measures

\begin{tabular}{|c|c|c|c|c|c|c|c|}
\hline Equation No. & & \multicolumn{2}{|l|}{5} & \multicolumn{2}{|l|}{5} & \multicolumn{2}{|l|}{6} \\
\hline Dependent Variable & & \multicolumn{2}{|c|}{ RESTATE } & \multicolumn{2}{|c|}{$F I R S T \_G C O$} & \multicolumn{2}{|c|}{$M B E X$} \\
\hline Variables & expected sign & Coefficient & z-statistics & Coefficient & z-statistics & Coefficient & z-statistics \\
\hline ABAFEE & $+/-$ & $-1.06321 * *$ & -2.29 & 0.28371 & 0.38 & $-0.78682 * *$ & -2.49 \\
\hline DPABAFEE & $+/$ & 0.25734 & 0.59 & -0.07601 & -0.16 & 0.28121 & 1.17 \\
\hline PABAFEE & $+/-$ & $1.28305 *$ & 1.68 & 0.72911 & 0.83 & $1.06171 * *$ & 2.23 \\
\hline LNTA & $+/-$ & $0.20055 * *$ & 2.26 & 0.06541 & 0.67 & 0.03693 & 0.38 \\
\hline$A G E$ & $+/-$ & -0.00366 & -1.06 & 0.00368 & 1.27 & 0.00219 & 1.27 \\
\hline$B T M$ & $+/-$ & 0.22798 & 0.94 & 0.02524 & 0.12 & -0.17904 & -1.08 \\
\hline GROWTH & $+/-$ & 0.17028 & 0.79 & -0.49046 & -1.49 & 0.13768 & 0.48 \\
\hline ISSUE & $+/-$ & 0.07550 & 0.24 & 0.31052 & 0.99 & -0.13910 & -0.96 \\
\hline $\mathrm{CFO}$ & $+/-$ & -0.83822 & -1.13 & 0.59770 & 0.94 & 0.49947 & 1.45 \\
\hline LOSS & + & 0.49188 & 1.30 & $2.83660 * * *$ & 4.78 & $-1.00477 * * *$ & -4.90 \\
\hline CHGLEVE & + & -0.76680 & -0.75 & 1.24611 & 1.59 & -0.42186 & -0.54 \\
\hline ZSCORE & + & 0.02068 & 0.23 & $0.12651 *$ & 1.72 & $-0.20852 * *$ & -2.34 \\
\hline$B I G 5$ & - & $-0.76987 * *$ & -2.52 & -0.05895 & -0.21 & $0.34925 *$ & 1.87 \\
\hline INITIAL & + & $0.62885 *$ & 1.85 & 0.19417 & 0.50 & 0.20125 & 0.91 \\
\hline$L N N F C$ & - & & & & & -0.05908 & -0.43 \\
\hline$S T D F C$ & $+/-$ & & & & & $-1.14718 * * *$ & -3.53 \\
\hline Firm Years & & \multicolumn{2}{|c|}{2,334} & \multicolumn{2}{|c|}{1,068} & \multicolumn{2}{|c|}{1,013} \\
\hline Pseudo $\mathbf{R}^{2}$ & & \multicolumn{2}{|c|}{0.0703} & \multicolumn{2}{|c|}{0.2809} & \multicolumn{2}{|c|}{0.0868} \\
\hline
\end{tabular}

This table shows the coefficients and t-statistics for estimating Equation (5) for RESTATE and FIRST_GCO, respectively, and Equation (6) for MBEX as logistic regressions that include fixed effects for fiscal year and industry. The analyses employ heteroskedasticity-adjusted robust standard errors clustered by firm. The regressions are estimated with an intercept included (not tabulated). $* * *, * *$, and $*$ denote p-value significance at the $1 \%, 5 \%$ and $10 \%$ levels, with two-tailed tests. All variables are defined in Appendix 1. 